\title{
Current Perspectives on Severe Drug Eruption
}

\author{
Jingzhan Zhang ${ }^{1,2} \cdot$ Zixian Lei $^{1,2} \cdot$ Chen Xu ${ }^{1,2} \cdot$ Juan Zhao ${ }^{1,2} \cdot$ Xiaojing Kang $^{1,2}(\mathbb{0}$ \\ Accepted: 20 April 2021 / Published online: 17 July 2021 \\ (c) The Author(s), under exclusive licence to Springer Science+Business Media, LLC, part of Springer Nature 2021
}

\begin{abstract}
Adverse drug reactions involving the skin are commonly known as drug eruptions. Severe drug eruption may cause severe cutaneous adverse drug reactions (SCARs), which are considered to be fatal and life-threatening, including Stevens-Johnson syndrome (SJS), toxic epidermal necrolysis (TEN), acute generalized exanthematous pustulosis (AGEP), and drug reaction with eosinophilia and systemic symptoms (DRESS). Although cases are relatively rare, approximately $2 \%$ of hospitalized patients are affected by SCARs. There is an incidence of 2 to 7 cases/million per year of SJS/TEN and 1/1000 to 1/10,000 exposures to offending agents result in DRESS. However, the mortality rate of severe drug eruptions can reach up to $50 \%$. SCARs represent a real medical emergency, and early identification and proper management are critical to survival. The common pathogenesis of severe drug eruptions includes genetic linkage with HLA- and non-HLA-genes, drug-specific T cell-mediated cytotoxicity, $\mathrm{T}$ cell receptor restriction, and cytotoxicity mechanisms. A multidisciplinary approach is required for acute management. Immediate withdrawal of potentially causative drugs and specific supportive treatment is of great importance. Immunoglobulins, systemic corticosteroids, and cyclosporine A are the most frequently used treatments for SCARs; additionally, new biologics and plasma exchange are reasonable strategies to reduce mortality. Although there are many treatment methods for severe drug eruption, controversies remain regarding the timing and dosage of drug eruption. Types, dosages, and indications of new biological agents, such as tumor necrosis factor antagonists, mepolizumab, and omalizumab, are still under exploration. This review summarizes the clinical characteristics, risk factors, pathogenesis, and treatment strategies of severe drug eruption to guide clinical management.
\end{abstract}

Keywords Severe drug eruption - Stevens-Johnson syndrome - Toxic epidermal necrolysis · Acute generalized exanthematous pustulosis · Drug reaction with eosinophilia and systemic symptoms

$\begin{array}{ll}\text { Abbreviations } \\ \text { AGEP } & \text { Acute generalized exanthematous pustulosis } \\ \text { ALT } & \text { Alanine aminotransferase } \\ \text { APCs } & \text { Antigen-presenting cells } \\ \text { AST } & \text { Aspartate aminotransferase } \\ \text { CBZ } & \text { Carbamazepine } \\ \text { CCR } & \text { CC-chemokine receptor } \\ \text { COVID-19 } & \text { Coronavirus disease } 2019 \\ \text { CTL } & \text { Cytotoxic T cells } \\ \text { CXCR } & \text { CXC chemokine receptor } \\ \text { DiHS } & \text { Drug-induced hypersensitivity syndrome }\end{array}$

Xiaojing Kang

drkangxj666@163.com

1 Department of Dermatology, People's Hospital of Xinjiang Uygur Autonomous Region, Tianshan District, No. 91, Tianchi Road, Urumqi 830001, Xinjiang, China

2 Xinjiang Key Laboratory of Dermatology Research, Urumqi, Xinjiang, China
DRESS Drug reaction with eosinophilia and systemic symptoms

EBV Epstein-Barr virus

ESR Erythrocyte sedimentation rate

FasL Fas ligand

FADD Fas-associated death domain protein

HHV Human herpesvirus

HIV Human immunodeficiency virus

HLAs Human leukocyte antigens

HMGB-1 High-migration protein-1

Ig Immunoglobulin

IL Interleukin

IVIG Intravenous immunoglobulin

J-SCAR Japanese Research Committee on Severe Cutaneous Adverse Reaction

KC Keratinocytes

MCP Monocyte chemotactic proteins

MHC Major histocompatibility complex

NF-kB Nuclear transcription factor-kappa B 


$\begin{array}{ll}\text { NK cells } & \text { Natural killer cells } \\ \text { NSAIDs } & \text { Non-steroidal anti-inflammatory drugs } \\ \text { TCR } & \text { T cell receptor } \\ \text { TEN } & \text { Toxic epidermal necrolysis } \\ \text { Th17 } & \text { T helper type 17 } \\ \text { TNF } & \text { Tumor necrosis factor } \\ \text { RegiSCAR } & \text { European Registry of Serious Adverse Skin } \\ & \text { Reactions } \\ \text { SCARs } & \text { Severe cutaneous adverse drug reactions } \\ \text { SCORTEN } & \text { Score of Toxic Epidermal Necrolysis } \\ \text { SJS } & \text { Stevens-Johnson syndrome }\end{array}$

\section{Introduction}

Adverse drug reactions are defined as unexpected and harmful reactions to a conventional drug dose [1]. They are generally divided into two categories: dose-related drug reactions, which are predictable and determined by the characteristics of the drug itself, and non-dose-related drug reactions, which are unpredictable and related to both personal constitution and the drug itself. Drug eruptions generally belong in the latter category. According to relevant literature reports, drug eruption accounts for $25 \%-30 \%$ of adverse drug reactions [2]. Drug stimulation, also known as dermatitis medicamentosa, refers to the inflammatory reaction of the skin and mucosa caused by ingestion of drugs into the human body through any of the following routes of administration: oral, injection, inhalation, suppository, perfusion, or absorption. Drug-induced dermatitis is a common disease in dermatology, and reportedly, drug eruption accounts for $2 \%-5 \%$ of all skin diseases [3]. Most patients can be cured by immediate withdrawal from the sensitizing drug and administration of an anti-allergic treatment. However, severe cutaneous adverse drug reactions (SCARs) not only have a sudden onset and extensive and serious skin lesions, which may even involve the oral mucosa, they may also cause systemic poisoning symptoms that involve multiple organs, serious damage to liver and kidney functions, and even life-threatening conditions, such as severe drug stimulation [4-6].

Patients with SCARs have severe conditions, which progress rapidly and are often life-threatening due to secondary infection, water and electrolyte disorders, and multiple organ failure. The etiology of a severe drug eruption is complex and remains unclear. The increased risk of allergic reactions to certain drugs may be associated with specific human leukocyte antigens (HLAs). Currently, the common pathogenesis of severe drug eruptions includes genetic linkage with HLA- and non-HLA-genes, drug-specific T cell-mediated cytotoxicity, T cell receptor (TCR) restriction, and cytotoxicity mechanisms $[7,8]$. Although there are many treatment methods for severe drug eruption, controversies remain regarding the timing and dosage of drug eruption. Types, dosages, and indications of new biological agents, such as tumor necrosis factor (TNF) antagonists and mepolizumab, are still under exploration. Understanding the clinical characteristics, treatment, and prognosis of severe drug eruptions from common sensitizing drugs will help clinicians monitor and prevent severe drug eruption, avoid drug abuse, and reduce its incidence and mortality. This study reviews the research progress and discusses the most recent evidence to guide clinical management.

\section{Epidemiology}

Although cases are relatively rare, approximately $2 \%$ of hospitalized patients are affected by SCARs [9]. There is an incidence of 2 to 7 cases/million per year of StevensJohnson syndrome/toxic epidermal necrolysis (SJS/TEN) [10-13], and $1 / 1000$ to $1 / 10,000$ exposures to offending agents result in drug reaction with eosinophilia and systemic symptoms (DRESS) [14]. However, mortality rates are gradually increasing from SJS, SJS-TEN overlap, and TEN to DRESS, which are approximately 5\%-10\%, 30\%, $50 \%$, and $10 \%$, respectively [15-19].

Many studies have confirmed that antiepileptic drugs are associated with a high risk of SCARs. In the European Registry of Serious Adverse Skin Reactions (RegiSCAR), carbamazepine is considered to be the most common reason for DRESS [19] and the second most common cause of SJS and TEN. Other antiepileptic drugs are also associated with SCARs [20]. The SCARs risk associated with various drugs depends on a number of variables, including genetic and non-genetic risk factors. The prevalence and pattern of SCARs vary widely among different races and geographic distributions. A strong connection between HLA alleles and drug-induced cutaneous reactions has been identified in numerous studies [21]. In European and Japanese populations, the HLA-A*31.01 allele has been linked to carbamazepine (CBZ)-induced adverse reactions [18]. However, among Han Chinese, Vietnamese, Taiwanese, and other Southeast Asian descendants, the HLA-B*15:02 allele has been associated with CBZ-induced hypersensitivity reactions. Furthermore, allopurinol-induced SJS and TEN were found to have a strong correlation with the HLA-B*58:01 genotype, as this study obtained consistent results in patients in Southeast Asia, Japan, and Europe [21, 22].

Host factors that increase the risk of scarring include systemic lupus erythematosus, the presence of potential malignancies, and potential infections, such as tuberculosis, hepatitis [23], human immunodeficiency virus (HIV) [24], and coronavirus disease 2019 (COVID-19) [25]. Potential infections not only increase the risk of scarring but also lead to more severe disease phenotypes, including an increased 
risk of visceral system damage and ophthalmic complications [26]. In recent years, the use of more biological agents and anti-tumor drugs has also increased the risk of SCARs [27]. In addition, prescription habits can also affect the risk of scarring. For example, a dose greater than or equal to $200 \mathrm{mg}$ of allopurinol per day is associated with a high risk of SJS/TEN [28]. In addition to the common drugs related to SCARs [29-32] (Table 1), Chinese materia medica and new sensitizing drugs have been reported [33], such as antihypertensive drugs (cannabinol [34], hydrochlorothiazide [35]), antifungal drugs (griseofulvin [36], terbinafine [37]), and non-steroidal anti-aromatase (letrozole) [38].

\section{Pathogenesis of SCARs}

In recent years, great progress has been made in the study of the pathophysiological mechanisms of drug eruption, which are described below.

Because of their small molecular weight, drugs must form complexes with tissues to produce an immune response. Currently, there are three hypotheses regarding drug-tissue complex interactions, which are as follows [39]: in the hapten/prohapten precursor model, drugs or their metabolites covalently bind to endogenous proteins in the body to form "complete antigen complexes," which are regarded as foreign substances and undergo treatment and processing by antigen-presenting cells (APCs) to form "major histocompatibility complex (MHC)-antigen peptide complexes" for
TCR recognition; (2) in the pharmacological and immune receptor interaction model, inert drugs that cannot covalently bind to endogenous proteins in the body bind to TCR and trigger a T-cell response due to their special configuration; and (3) in the peptide model, drugs or metabolites are directly attached to the covalent slot of MHC proteins, thereby changing the specificity of MHC molecules to peptides. These altered MHC proteins are then considered foreign antigens by the body and trigger a series of immune responses designed to remove foreign antigens [40]. HLA molecules play a key role in $\mathrm{T}$ cell activation by presenting processed antigens to the TCRs expressed on T cells. HLA class I and class II molecules initiate immune responses by presenting antigens to $\mathrm{CD} 8+$ (cytotoxic) and $\mathrm{CD} 4+$ (helper) T cells [41]. Because HLA molecules present a variety of "self" and "non-self" peptides, HLA genes are significantly polymorphic [42]. Currently, HLA molecules with specific adverse drug reactions have been found, including abacavir, allopurinol, carbamazepine, and phenytoin [39].

Drug-tissue complexes induce the overexpression of cytotoxic molecules, FasL, on keratinocytes (KC), while cytotoxic T cells (CTL), natural killer (NK) cells, and monocytes secrete granulocytin and membrane-linked protein $\mathrm{A} 1$, and so on, that induce the apoptosis of $\mathrm{KC}$ in different ways [43]. The Fas/Fas ligand (FasL) complex binds to the Fas-associated death domain protein (FADD), which simultaneously recruits procaspase 8 , a cell apoptotic protease, in a multi-copy manner, leading to intracellular DNA degradation. CD8 $+\mathrm{T}$ cells specifically recognize $\mathrm{KC}$ and

Table 1 Drugs most commonly reported to induce SCARs [29-32]

\begin{tabular}{llc}
\hline SJS/TEN & AGEP & DRESS \\
\hline $\begin{array}{l}\text { Anticonvulsants } \\
\text { Phenytoin, carbamazepine, lamotrigine, phenobarbitone }\end{array}$ & $\begin{array}{l}\text { Anticonvulsants } \\
\text { Phenytoin, carbamazepine, lamotrigine, phenobarbitone }\end{array}$ & $\begin{array}{c}\text { Anticonvulsants } \\
\text { Phenytoin, carba- } \\
\text { mazepine, lamo- } \\
\text { trigine, phenobar- } \\
\text { bitone }\end{array}$ \\
& & NSAIDs \\
NSAIDs & & Oxicam-NSAIDs, \\
Oxicam-NSAIDs, diclofenac, phenylbutazone & NSAIDs & diclofenac, phe- \\
& Oxicam-NSAIDs, diclofenac, phenylbutazone & Antiretrovirals \\
Antibiotics & & Nevirapine, abacavir \\
Sulphonamides, penicillins, quinolones, macrolides & Antibiotics & Alphonamides, penicillins, quinolones, macrolides, tetracy- \\
& clines, vancomycin & Dapsone \\
Antiretrovirals & Anti-leprosy & Anti-gout \\
Nevirapine, abacavir & Dapsone & Allopurinol \\
Antituberculous & Anti-gout & Anti-leprosy \\
Isoniazid, ethambutol & Allopurinol & Dapsone \\
Anxiolytics & & \\
Alprazolam & & \\
Anti-gout & & \\
Allopurinol & &
\end{tabular}


secrete toxic molecules (perforin, granzyme B, granulysin) into the cytoplasm through tiny cell pores, mediating $\mathrm{KC}$ apoptosis and mutual separation. Membrane-bound protein A1 is a substance found in the supernatant of peripheral blood mononuclear cells of patients who naturally recover after SJS/ TEN, which triggers $\mathrm{KC}$ apoptosis through the "membranebound protein A1 receptor." In addition, Ichihara et al. observed increased levels of Mir-18a-5P in the skin of TEN patients and revealed that Mir-18a-5p could downregulate the expression of B-cell lymphoma/leukemia-2 like protein 10 (an anti-endogenous apoptotic protein) and induce intrinsic KC apoptosis [40]. Particles of lysin also directly induce $\mathrm{KC}$ apoptosis and, by activating a precursor of the normal $\mathrm{T}$ cells, secrete inflammatory cytokines and chemokine T cells, monocytes, and other inflammatory cells in the skin. These cytokines include CCL3 and CCL5, CCL20 and monocyte chemotactic proteins 1 and 3 (MCP-1-3), IL-10, IL-1, IL-6, IL-interferon alpha, IL-2, IL-18, CC-chemokine receptor (CCR) 3, CXC chemokine receptor (CXCR) 3, CXCR4, and CCR10.

The epidermal chemokines of $\mathrm{T}$ cells expressed in patients' skin can attract peripheral blood CTL to migrate to the skin and play a cytotoxic role. Navarini et al. found that a mutation in the gene encoding IL-36 causes it to lose regulation, and the secretion of IL-6, IL-8, and IL-1 is enhanced, driving neutrophils to penetrate the epidermis [5]. In addition, IL-17 is secreted by T helper type 17 (Th17) cells in the patient's blisters to recruit neutrophils, and Th17 cells may differentiate and transform into Treg cells [44]. Virus reactivation, especially human herpesvirus 6 (HHV-6) reactivation, is a characteristic feature of DRESS. The interaction between the antiviral immune response and hypersensitivity to the drug increases the disease complexity and prolongs the disease course. Like SJS/TEN, DRESS is also a $\mathrm{T}$ cell-mediated immune response, with $90 \%$ of DRESS patients showing significantly increased CD4 $+\mathrm{T}$ cells in the acute phase. Takahashi et al. proposed that regulatory $\mathrm{T}$ cells (Treg) play a key role in the onset of the acute phase of DRESS [45]. In humans with latent HHV-6 infection, monocytes in the blood are the best place to hide. HHV-6, hidden in circulating monocytes, expresses the skin regression molecule CCR. These infected monocytes respond to highmigration protein-1 (HMGB-1) [46]. Monocytes containing the infected virus migrate into the skin and are presented to innate immune CD4 + T cells. Simultaneously, the number of memory $\mathrm{T}$ cells in the lesion increases. Large amounts of IL-4, IL-5, and IL-13 can promote the differentiation and maturation of eosinophils.

Several genetic factors causing a predisposition to severe drug eruption have been previously reported, including metabolic enzyme mutations or specific HLA-A, B, or C alleles. Strong associations have been established between the HLA-B*15:02 allele and CBZ-triggered SJS and TEN and between the HLA-B*58:01 allele and allopurinolinduced SJS and TEN or DRESS syndrome [47]. A mutation of the IL 36 receptor antagonist gene was suggested to be a genetic factor in acute generalized exanthematous pustulosis (AGEP) [48]. A restricted role of T-cell receptor clonotype has been proposed in CBZ-induced severe drug eruption since a T-cell receptor clonotype role has been connected with individuals positive for HLA-B*15:02 with SJS or TEN, which is absent in all carbamazepine-tolerant HLA$B^{*}$ 15:02 carriers [49]. In allopurinol-induced severe drug eruption, a specific T-cell receptor clonotype was identified as a reaction to its metabolite oxypurinol as well as the HLAB*5801 allele [50]. Various severe drug eruption phenotypes with the same drug-HLA association have been identified, including allopurinol-induced SJS and TEN or DRESS syndrome and HLA-B*58:01; carbamazepine-induced SJS and TEN or DRESS syndrome and HLA-B*15:02; exclusive drug-HLA associations with one phenotype, that is, dapsone hypersensitivity with the HLA-B*13:01 allele; and phenytoin-induced SJS and TEN with the HLA$B^{*}$ 15:02 allele [51]. In addition, genome-wide association studies have identified a variant of the cytochrome P450 2C9 enzyme, which is an important genetic factor in phenytoinrelated severe drug eruption, which is known to reduce drug clearance [52]. Other studies have proposed an ABC transporter and proteasome pathway mutation in non-drugspecific SJS and TEN [53].

\section{Clinical Presentation of SCARs}

SCARs include SJS, TEN, DRESS, and AGEP. The incubation period, clinical presentation, laboratory examination, main organs involved, death rate, and histological features are shown in Table 2.

\section{SJS/TEN}

Pleomorphic erythema drug eruption is characterized by soybean- to broad bean-sized round or oval edematous erythema or papules, with blisters at the center and redness on the edge, and often has a symmetrical occurrence. When accompanied by mouth, eye, and vulvar mucosal involvement, blisters can be eroded, which when accompanied by severe pain, high fever, liver, and kidney function damage, is considered SJS, the most serious type of drug eruption. Bullous epidermolysis drug eruption belongs to the same disease spectrum as SJS. The general incubation period from drug exposure to symptoms is about 4-28 days and is rarely more than 8 weeks. There is often a prodromal period before onset, which is characterized by fever, cough, fatigue, arthralgia, rhinitis, eye tingling, conjunctivitis, dysphagia caused by oral ulcers, or urine pain caused by genital lesions. 
Table 2 Main clinical and pathological features of SCARs

\begin{tabular}{|c|c|c|c|c|c|c|}
\hline & Incubation period & Clinical presentation & Laboratory examination & Main organs involved & Death rate & Histological features \\
\hline $\begin{array}{l}\text { SJS and TEN } \\
{[54-56]}\end{array}$ & 4 28days & $\begin{array}{l}\text { Erythema, macular } \\
\text { papules, urticaria, } \\
\text { purpura or target rash, } \\
\text { loose blisters that can } \\
\text { fuse into bullae, caus- } \\
\text { ing skin epidermis to } \\
\text { peel off }\end{array}$ & $\begin{array}{l}\text { Lymphocytopenia, tran- } \\
\text { sient neutropenia, mild } \\
\text { cytolysis, renal damage }\end{array}$ & $\begin{array}{l}\text { Oral and genital mucosa, } \\
\text { liver, kidney, lung, gas- } \\
\text { trointestinal tract, eyes, } \\
\text { urethra, etc. }\end{array}$ & $25 \%$ & $\begin{array}{l}\text { The whole layer of } \\
\text { epidermis is necrotic, } \\
\text { resulting in epidermal } \\
\text { separation and a small } \\
\text { amount of monocyte } \\
\text { infiltration in the } \\
\text { papillary layer of the } \\
\text { dermis. }\end{array}$ \\
\hline $\begin{array}{l}\text { DRESS } \\
{[58-62]}\end{array}$ & 2 6weeks & $\begin{array}{l}\text { Measles-like rash with } \\
\text { small pustules and, in } \\
\text { severe cases, erythro- } \\
\text { derma with extensive } \\
\text { exfoliation of the skin, } \\
\text { fever, enlarged lymph } \\
\text { nodes, accompanied } \\
\text { by fever and enlarged } \\
\text { lymph nodes }\end{array}$ & $\begin{array}{l}\text { Eosinophilia, monocyto- } \\
\text { sis, and thrombocyto- } \\
\text { penia }\end{array}$ & $\begin{array}{l}\text { Liver, kidney, lung, heart, } \\
\text { lymph node, brain, eye, etc. }\end{array}$ & $10 \%$ & $\begin{array}{l}\text { Keratinocyte necrosis, } \\
\text { lymphocyte extravasa- } \\
\text { tion, surface sponge } \\
\text { edema, interfacial } \\
\text { vacuolar degeneration, } \\
\text { dermal lymphocyte } \\
\text { and eosinophil infil- } \\
\text { tration }\end{array}$ \\
\hline $\begin{array}{l}\text { AGEP } \\
{[65-69]}\end{array}$ & 1 11days & $\begin{array}{l}\text { Joint, face, rash is aseptic } \\
\text { pustule, less mucosal } \\
\text { involvement, body tem- } \\
\text { perature often }>38^{\circ} \mathrm{C}\end{array}$ & $\begin{array}{l}\text { White blood cells and } \\
\text { neutrophils are mostly } \\
\text { elevated. }\end{array}$ & Liver, kidney, lung, etc. & $5 \%$ & $\begin{array}{l}\text { Spongy pustules under } \\
\text { the cornea and(or) } \\
\text { epidermis, papillary } \\
\text { dermis and perivascu- } \\
\text { lar edema, neutrophil } \\
\text { and eosinophil infil- } \\
\text { tration. Individual cell } \\
\text { necrosis with vasculi- } \\
\text { tis or keratinocytes }\end{array}$ \\
\hline
\end{tabular}

Clinical manifestations include erythema, macular papules, urticaria, purpura, or target rash. Within 3-4 days, skin lesions develop rapidly on the face, neck, and limbs, while the scalp is rarely involved. Blisters of different sizes then appear in the erythema and quickly fuse into bullae, resulting in the peeling off of the skin epidermis and positive Nissl's sign, leaving a bright red eroded surface and exudation, which is susceptible to bacterial infection (Fig. 1). Sepsis is the leading cause of death. If the lesion continues to develop, mucosal erosion can occur in the lips, tongue, oral cavity, nasal cavity, pharynx, larynx, conjunctiva, vagina, urethra, gastrointestinal tract, and respiratory tract. Eye involvement may occur in $80 \%$ of patients [54]. The gastrointestinal tract can be involved, and gastrointestinal bleeding and colon perforation may occur. Approximately $30 \%$ of patients have respiratory involvement [55], including pneumonia, bronchitis, and obvious hypoxemia. Other complications include abnormal liver function, myocarditis, acute tubular necrosis, glomerulonephritis, acute renal failure, pulmonary edema, and acute respiratory distress syndrome (Table 3). Score of Toxic Epidermal Necrolysis (SCORTEN) is a rating system for the severity of the disease [56] (Table 4). Histopathological
Fig. 1 Skin damage. a Conjunctiva. b Labial mucosa. c Target erythema. d Epidermolysis
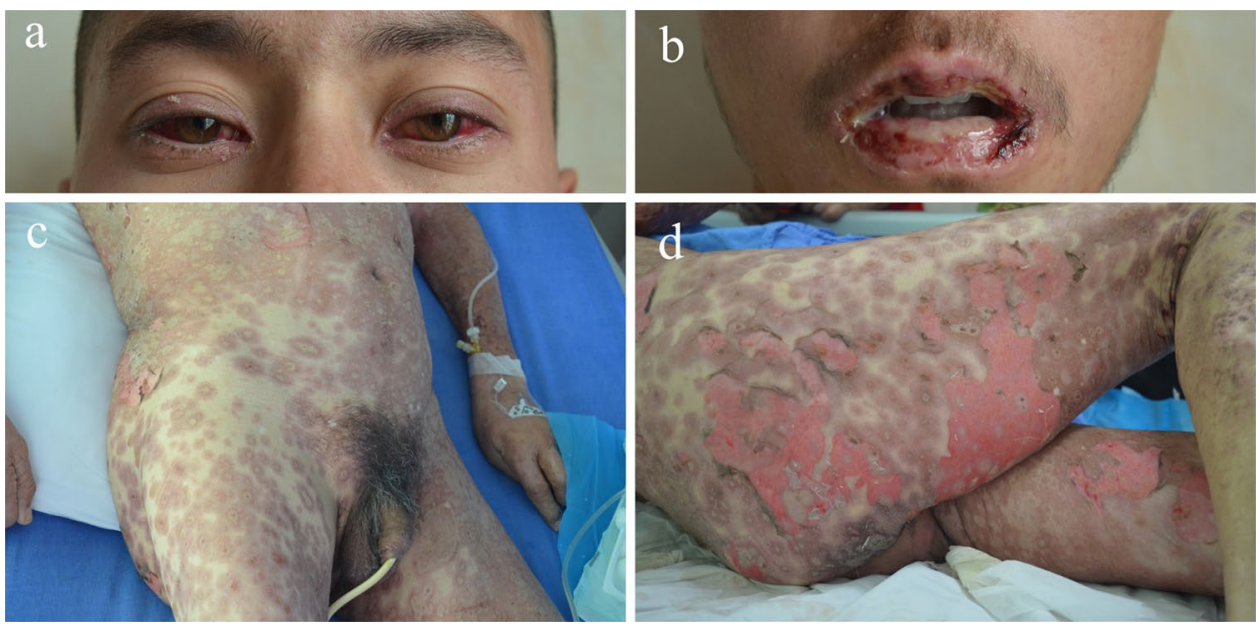
Table 3 SJS, SJS/TEN, TEN clinical differentiation [54-56]

\begin{tabular}{llll}
\hline Clinical & SJS & SJS/TEN & TEN \\
\hline Target damage & + & + & + \\
Mucosal damage & + & + & + \\
Systemic symptoms & + & ++ & ++ \\
Exfoliated area & $<10 \%$ & $10 \% \sim 30 \%$ & $>30 \%$ \\
Distribution & Torso & Head, & Head, torso, \\
& based & torso & limbs \\
\hline
\end{tabular}

examination reveals a necrotic epidermal layer, resulting in epidermal separation and a small amount of monocyte infiltration in the papillary layer of the dermis.

In addition to systemic complications, severe drug eruptions incorporating a large skin area can also produce severe sequelae. In a large retrospective cohort study [57], followup of adult patients with SJS/TEN revealed that nearly half of them had long-term sequelae, involving the eyes (corneal ulcers, cicatricial lesions, and shortening of the fornix and symblepharon), skin, gastrointestinal tract, genitals (erosion of genital mucosa may lead to vaginal adhesion), kidneys, lungs, and nails [58] (Fig. 2). The most common sequelae are ocular, skin, genital, oral, renal, and gastrointestinal sequelae as well as depression, anxiety, chronic pain, tinnitus, and amputation [59].

\section{DRESS}

DRESS is a serious and potentially fatal adverse effect of therapeutic medications, also known as drug-induced hypersensitivity syndrome (DiHS), with a fatality rate of approximately $10 \%$. It can be accompanied by rash, fever, and internal organ involvement and usually manifests as a measles-like eruption, with small pustules and erythroderma with extensive skin peeling in severe cases (Fig. 3). Multiple internal organs can be damaged; patients with underlying diseases and the elderly are more likely to have internal organ involvement. Eosinophilia, thrombocytopenia, acute severe hepatitis, hepatomegaly, jaundice, lymphadenopathy, enteritis, intestinal bleeding, nephritis, and respiratory

Table 4 Severity of illness score for toxic epidermal necrolysis [56]

\begin{tabular}{llll}
\hline Clinical parameter & Point & Total score & Mortality rate \\
\hline Age $>40$ years & 1 & $0-1$ & $3.2 \%$ \\
Malignancy & 1 & 2 & $12.2 \%$ \\
Tachycardia $>120 / \mathrm{min}$ & 1 & 3 & $35.5 \%$ \\
Initial area of detachment $>10 \%$ & 1 & 4 & $58.3 \%$ \\
Serum urea $>10 \mathrm{mmol} / \mathrm{L}$ & 1 & 5 or more & $90.0 \%$ \\
Serum glucose $>14 \mathrm{mmol} / \mathrm{L}$ & 1 & & \\
Bicarbonate $<20 \mathrm{mmol} / \mathrm{L}$ & 1 & & \\
\hline
\end{tabular}

distress syndrome can occur. Neurological diseases, such as meningitis or encephalitis, can also occur within 2 to 4 weeks of onset [60]. In severe cases, liver failure may be the leading cause of death in DRESS. Some patients may have ocular complications, such as double-eye corneal infiltration and acute anterior uveitis [61]. There are also reports that patients with DRESS can have general alopecia. The histopathological examination may reveal keratinocyte necrosis, lymphocyte extravasation, surface sponge edema, interfacial vacuolar degeneration, dermal lymphocyte, and eosinophil infiltration.

DRESS patients may also develop late sequelae after cure, which most often involve the liver. An enlarged liver and spleen are common, and liver failure can lead to death. Renal dysfunction is most common in elderly patients with renal disease, which may eventually progress to renal failure; thyroid disease, diabetes, lupus erythematosus, and myocarditis may also occur [19, 62-64].

At present, DRESS does not have a unified diagnostic standard, and diagnosis is mainly based on clinical manifestations and laboratory tests. In 1992, some scholars proposed that patients meeting the following three criteria could be diagnosed with DRESS: drug-induced rash; eosinophilia $\left(>1.5 \times 10^{9} / \mathrm{L}\right)$ and abnormal lymphocytes; symptoms of systemic involvement, including lymphadenopathy (diameter $>2 \mathrm{~cm}$, hepatitis, or transaminase at more than twice the normal value), interstitial nephritis, interstitial pneumonia, or carditis [65]. The diagnostic criteria proposed by the RegiSCAR also comprise the following three prerequisites for diagnosis: acute rash, suspected drug-related reactions, and hospitalization. Alternatively, three of the following four criteria can be used for diagnosis: fever (body temperature $>38^{\circ} \mathrm{C}$ ); enlargement of at least two lymph nodes; involvement of at least one internal organ (liver, kidney, heart, pancreas, or others); and at least one of the following hematological changes (increased or decreased lymphocytes, increased eosinophil percentage or absolute count, or decreased platelets).

The Japanese Research Committee on Severe Cutaneous Adverse Reaction (J-SCAR) [66] proposed the following diagnostic criteria: skin rash occurring after 3 weeks of application of certain drugs; symptoms persisting more than 2 weeks after stopping the disease-causing drugs; body temperature $>38^{\circ} \mathrm{C}$; liver damage (transaminase $>100 \mathrm{U} / \mathrm{L}$ ) or involvement of other organs; one of the following hematological changes: white blood cell count $>11 \times 10^{9} / \mathrm{L}$, abnormal lymphocytes $>5 \%$, eosinophil counts $>1.5 \times 10^{9} / \mathrm{L}$; enlarged lymph nodes; and reactivation of the HHV-6. Typical DRESS patients manifest all the abovementioned seven items above, while atypical DRESS patients may have between 1 and 5 of these items. 
Fig. 2 Nail damage in a patient with TEN. a Fingernails. b toenails
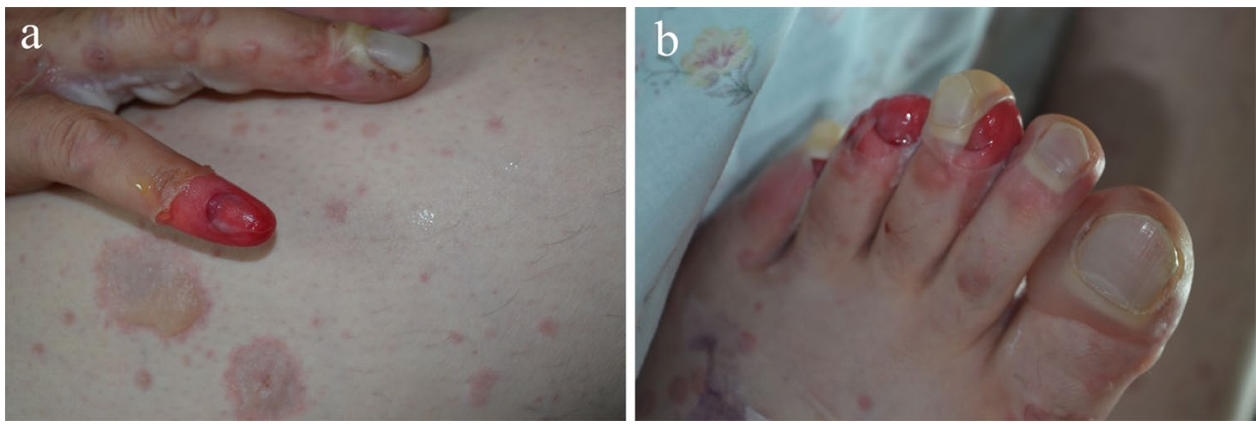

\section{AGEP}

AGEP is another severe drug eruption that may cause serious systemic involvement. The rash is mostly distributed on the joints and face, mainly manifested as small aseptic pustules, which are distributed on the basis of the edematous erythema (Fig. 4). Desquamation at the pustules may occur in approximately 1 week, accompanied by burning pain, itching, and discomfort. The Nikolsky sign may be positive or target erythema, purpura, blisters, bullae, and other rashes may occur. The genital mucosa is less affected; however, the oral or buccal mucosa may be affected and may be accompanied by fever (body temperature $>38^{\circ} \mathrm{C}$ ), and elevated white blood cells and neutrophil counts. Based on early manifestations, some may be misdiagnosed as acute infections [67]. Studies have reported that $17 \%$ of patients suffer from internal organ damage, such as liver insufficiency, renal insufficiency, and lung insufficiency [68]. Increases in alanine aminotransferase (ALT) and aspartate aminotransferase (AST) levels indicate liver damage; abdominal ultrasound can detect liver steatosis or liver enlargement [69]. Damage to the respiratory system may lead to the formation of pleural effusions, which can lead to dyspnea and hypoxemia in severe cases [70]. There are case reports of lymphadenopathy occurring in patients with AGEP [71]. The overall prognosis of this disease is good, and the fatality rate is less than 5\%. However, if system damages result in multiorgan failure or diffuse intravascular coagulation or if a large area of the mucosa is involved, there is a very high risk of death [72]. The typical histopathology of AGEP reveals spongy pustules under the cornea or epidermis. There is often obvious edema in the papillary dermis and surrounding blood vessels, accompanied by infiltration of neutrophils and eosinophils, as well as vasculitis or necrosis of individual cells of keratinocytes. Of note, this is different from the histopathology of psoriasis [73].

\section{Differential Diagnosis}

Pustules can appear in many skin diseases, and AGEP must be distinguished from many diseases, including pustular psoriasis, subcorneal pustulosist, and pustular vasculitis. While patients with AGEP may have a history of psoriasis, patients with pustular psoriasis have a history of psoriasis and usually have a generalized rash, long duration of pustules, high fever, and generally no history of drug allergy, and some patients will develop arthritis. Histopathologically, it manifests as the formation of large pustules, namely Kogoj pustules, mainly in the upper part of the epidermis, with neutrophils in the blisters, and the granular layer is significantly reduced or disappeared. The spinous layer thickens, the epidermal protrusion extends, the dermal papilla extends in a club-like shape, and the spinous layer above it becomes thinner.

Dilation and congestion of capillaries in the subcorneal pustulosist form mainly large, loose blisters, and abscess formation is usually distributed in a ring. In addition, the evolution of the disease is far less dramatic than that of AGEP. Pustular vasculitis is a special type of leukocyte destructive
Fig. 3 a Facial edema. b Measles-like rash over the body
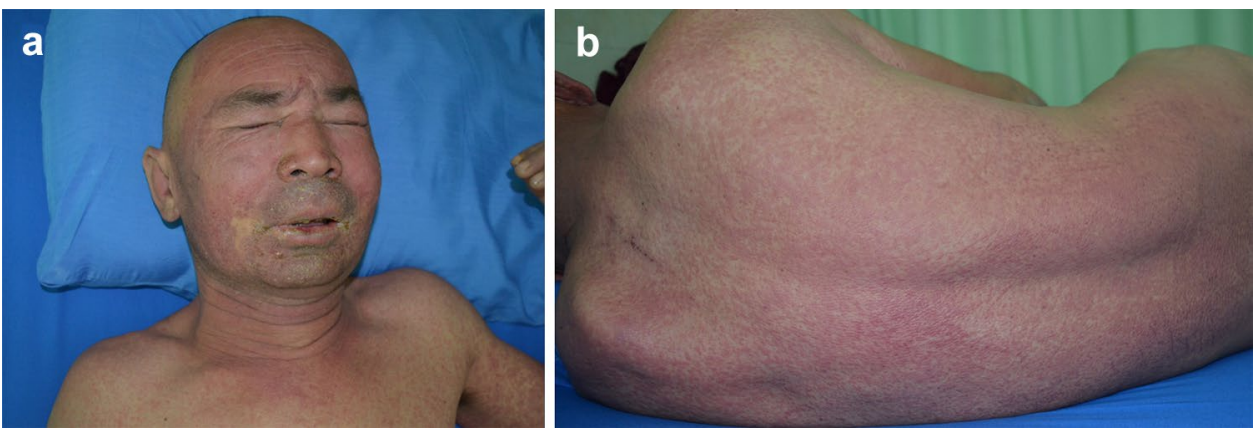
Fig. 4 Acute generalized exanthematous pustulosis

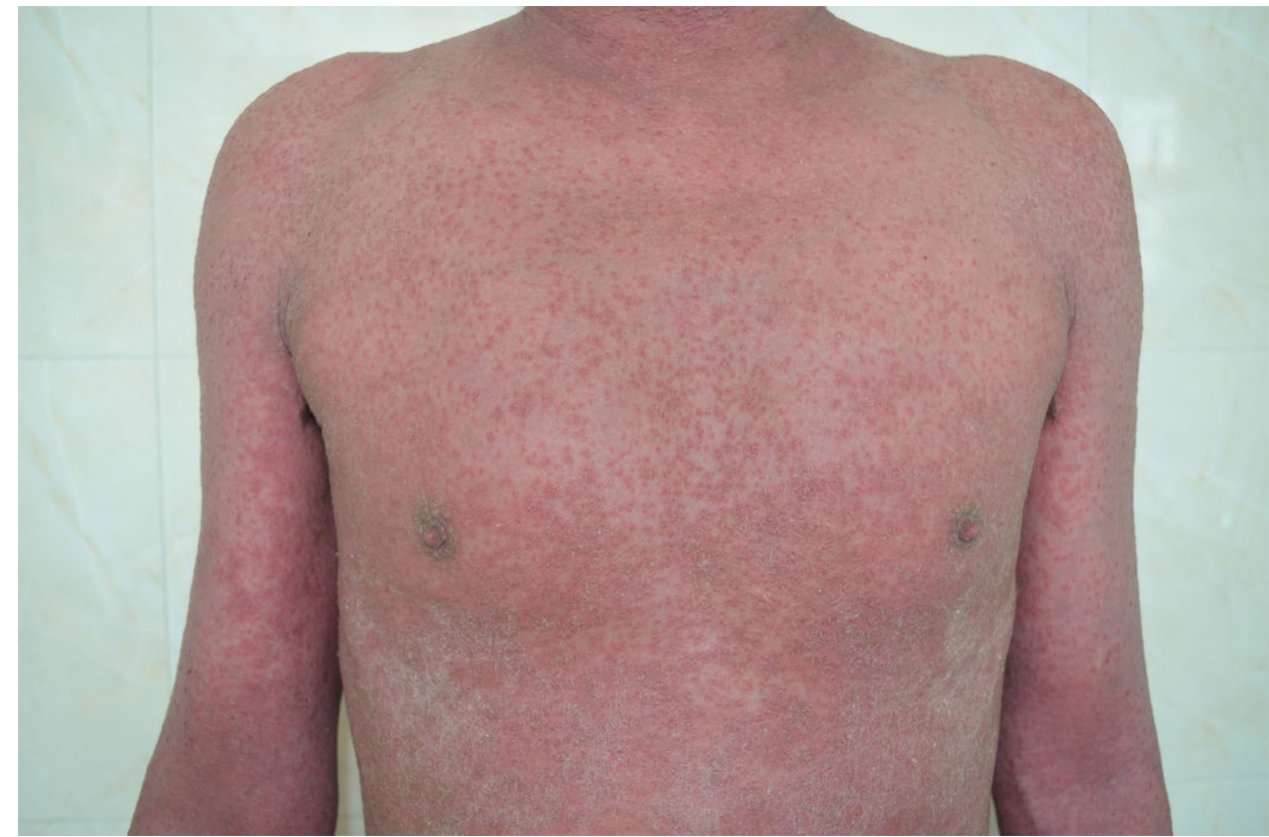

small vasculitis, which is characterized by the formation of many small pustules, which, in contrast to AGEP, are mainly confined to the back of the hand. Histologically, it can manifest as leukocyte-crushing vasculitis [74].

\section{SCARs in Pediatric Patients}

The morbidity of SJS, SJS-TEN, and TEN in children is lower than that in adults, mainly due to antibiotics and antiepileptic drugs. The mortality of patients with TEN is significantly higher than that of children with renal failure, septicemia, and bacterial infection in SJS or SJS-TEN [75]. More female than male patients develop pediatric DRESS [63]. While facial edema is less common in pediatric patients than in adults, pediatric DRESS patients are more likely to have fever, enlarged lymph nodes, and internal organs involvement, including the liver, kidney, heart, lung, brain, thyroid, and pancreas. Visceral involvement usually determines the disease severity. Liver damage and kidney damage are more common, and the overall mortality rate of DRESS in children is similar to that in adults [76]. Although there are few studies on children with AGEP, the most common reported causes include drugs, viruses, bacteria, and antibiotics [77].

\section{Therapy}

Although the incidence of a severe drug eruption is rare, patients are usually in critical condition and have multiple complications. The reported mortality rate associated with severe drug eruption is between 10 and 30\% [78, 79]. However, experts have not reached a consensus on certain treatments [80-82] (Table 5). Herein, we summarize the treatment status and research progress of severe drug eruptions.

\section{Symptomatic and Supportive Treatment}

Once a patient is suspected of or diagnosed with a severe drug eruption, the offending drug should be immediately withdrawn. Avoiding similar drugs (e.g., penicillin and amoxicillin) is highly recommended. The time of drug retention and drug half-life are related to the prognosis [83-85]. As severe drug eruption can cause a variety of complications, such as infection, hospitalization and a full examination, including routine blood and urine, erythrocyte sedimentation rate (ESR), liver function, renal function, and immunity tests, should be performed to obtain a clear understanding of the patient's condition [86].

The principle of therapy is the same as for burns. An airfluidized bed may reduce the incidence of pressure ulcers and thrombus $[87,88]$. According to research, delayed treatment increases mortality [89]. Burn center consultation and debridement may be required $[84,90,91]$. To reduce fluid loss and prevent infection on the body surface, the room temperature should be maintained at $30{ }^{\circ} \mathrm{C}-32{ }^{\circ} \mathrm{C}$, and the environment should be kept moist and clean. Patients likely experience a fluid and electrolyte imbalance due to the breakdown of the cutaneous barrier; therefore, moisturizers, oral intake of fluids, intravenous fluids, and nutritional support can be provided. Careful monitoring of heart function is recommended during treatment.

The destruction of the cutaneous barrier can also increase the risk of infection. Some studies have found that patients whose skin secretions showed a positive bacterial culture could develop sepsis 
Table 5 Guidelines for the treatment of SCAR in different countries

\begin{tabular}{|c|c|c|}
\hline & Recommended treatment & Other treatment \\
\hline TEN management in Japan [80] & $\begin{array}{l}\text { - The initial dose of glucocorticoid used in the system is } 0.5-2 \mathrm{mg} / \mathrm{kg} / \mathrm{day} \text { of meth- } \\
\text { ylprednisolone. If eye symptoms, respiratory symptoms or skin lesions are rapidly } \\
\text { expanding, it can be treated with } 500-1000 \mathrm{mg} / \text { day of methylprednisolone for } 3 \text { days. } \\
\text { - IVIG } 5 \sim 20 \mathrm{~g} / \text { day, lasting } 3 \sim 5 \text { days, no more than } 2 \mathrm{~g} / \mathrm{kg} \text {, currently } 0.4 \mathrm{~g} / \mathrm{kg} / \mathrm{day} \text { is } \\
\text { used for treatment for } 5 \text { days } \\
\text { - Plasmapheresis }\end{array}$ & Cyclosporine \\
\hline $\begin{array}{l}\text { Guidelines for the management } \\
\text { of SJS/TEN in India [81] }\end{array}$ & $\begin{array}{l}\text { - Early- and short-term system use of glucocorticoids. Intravenous infusion of methyl- } \\
\text { prednisolone } 20-30 \mathrm{mg} / \mathrm{kg} / \mathrm{day} \text {, intravenous infusion of dexamethasone } 1.5 \mathrm{mg} / \mathrm{kg} / \mathrm{day} \text {, } \\
\text { and methylprednisolone } 1000 \mathrm{mg} / \text { day shock treatment for } 3 \text { days } \\
\text { - Cyclosporine, orally } 3 \sim 5 \mathrm{mg} / \mathrm{kg} / \mathrm{day} \text {, but the course of treatment has not yet reached a } \\
\text { consensus. It has been reported in } 2 \text { weeks to } 1 \text { month } \\
\text { - IVIG, dosage, and time of administration are not uniform }\end{array}$ & $\begin{array}{l}\text { Cyclophosphamide } \\
\text { Plasmapheresis } \\
\text { G-CSF } \\
\text { TNF- } \alpha \text { inhibitor }\end{array}$ \\
\hline $\begin{array}{l}\text { U.K. guidelines for the man- } \\
\text { agement of SJS/TEN [82] }\end{array}$ & $\begin{array}{l}\text { - Most studies support the use of IVIG, especially in children; the course of treatment is } \\
3 \text { to } 5 \text { days, and the dose ranges from } 0.2 \text { to } 1 \mathrm{~g} / \mathrm{kg} / \mathrm{day} \\
\text { - Early administration of high-dose corticosteroids can suppress inflammation, but it } \\
\text { also increases the risk of sepsis } \\
\text { - Oral cyclosporine } 3 \mathrm{mg} / \mathrm{kg} / \text { day, gradually reduced after } 7 \text { days, the total course of } \\
\text { treatment is about } 2 \text { to } 4 \text { weeks }\end{array}$ & $\begin{array}{l}\text { Plasmapheresis } \\
\text { G-CSF } \\
\text { TNF- } \alpha \text { inhibitor }\end{array}$ \\
\hline
\end{tabular}

[92]. Another study demonstrated that patients tended to have a lower risk of infection if treated with empirical antibiotics. However, given the small number of patients observed, the authors do not suggest excessive antibiotics at an early stage [93]. Therefore, the frequent culture of mucocutaneous erosions and blood, topical antiseptics, and appropriate use of prophylactic antibiotics might be a reasonable treatment plan [94]. Other options, such as skin grafts, cryopreserved cutaneous allografts, skin substitutes, and biological dressings, can be used to minimize pain and dehydration [95-98]. In case of ocular involvement, it is necessary to administer antibiotic eye drops and steroid drops to prevent infection, corneal ulcers, conjunctivitis, and even symblepharon $[99,100]$. The most common complication of patients with severe drug eruption is hypovolemia caused by excessive body fluid loss. Other complications include cardiac insufficiency, respiratory inflammation, and peptic ulcer, which require multidisciplinary treatment [101]. Some patients may develop inferiority and anxiety during the course of illness, which could persist. It is important to address psychological complications to improve their quality of life [101-104].

\section{Systemic Corticosteroids}

Glucocorticoids have anti-inflammatory and immunosuppressive effects. They can inhibit the inflammatory response caused by immunocompetent cells and inhibit the activation of transcription factors (activator protein 1 and nuclear factor- $\kappa \mathrm{B})$, thereby inhibiting the immune response, eosinophil proliferation, and the production of inflammatory factors and antibodies. On the other hand, high-dose glucocorticoids can inhibit T cell-induced apoptosis of keratinocytes [105]. Consensus has not been established on the use of corticosteroids in the treatment of drug eruption because the evidence is limited and the results of the research are different.

The recommended dosage of prednisone is $1.0-1.5 \mathrm{mg} /$ $\mathrm{kg} /$ day, usually 40-60 mg/day. To avoid relapse, it is recommended to reduce the dosage gradually over a period of 2-3 months; some recommend tapering the dose for 3-6-months for DRESS. One report suggests that prompt short-term corticosteroid therapy appears to be the key to minimizing damage from TEN and DRESS [106]. Kocaoglu et al. found that pulse methylprednisolone at a dose of $30 \mathrm{mg} / \mathrm{kg}$ (maximum of $1 \mathrm{~g} / \mathrm{day}$ ) for 3 days could accelerate the recovery of liver function and fever [107]. Tetsuo Shiohara and others believe that the current standard treatment for DRESS is the systemic use of glucocorticoids, which can quickly control rash and fever [45, 65, 108-110]. By observing the treatment process of 91 patients with DRESS, Wei et al. found that patients who were treated with systemic glucocorticoids survived longer (36.3 versus 12.7 days). Of all the surviving patients, almost 3/4 of the patients used hormones, but their treatment duration was extended 8 days longer on average [111]. In addition, a long-term follow-up study in Singapore found that 25 of 27 DIHS/DRESS patients survived following treatment with glucocorticoids [112].

However, other studies have shown that treatment with glucocorticoids is related to an increase in morbidity and mortality. The death rate from infection in patients receiving steroid therapy is $66 \%$, while the death rate from infection in patients not receiving steroid therapy is $33 \%$, indicating that steroids increased the risk of sepsis, increased protein catabolism, and delayed epithelialization [113]. Guibal's research results show that long-term steroid therapy can delay the onset of TEN, but it cannot prevent the development of the disease [114]. In addition, long-term treatment with glucocorticoids can occur. Based 
on these observations, we can conclude that the treatment of TEN with corticosteroids may be harmful. However, Patterson reported that the nosocomial infection rate of short-term highdose intravenous steroid treatment with steroid therapy for SJS and TEN is lower than that of placebo-treated burn department inpatients, although that study was theoretically limited to the early treatment (such as within 20 days) of patients $[115,116]$.

\section{Intravenous Immunoglobulin}

According to research, intravenous immunoglobulin (IVIG) may block Fas-FasL binding, interrupting the signal transduction of apoptosis, thereby preventing drug-induced necrosis of keratinocytes. It can also be combined with circulating immune complexes to form insoluble complexes with prompt clearance by reticuloendothelial cells and can bind to specific B cell receptors to downregulate their functions and reduce pathogenic antibody synthesis [117]. Therefore, some experts recommended IVIG for patients with life-threatening DRESS [118]. Early administration of high doses $(\leq 2 \mathrm{~g} / \mathrm{kg})$ is recommended in TEN. Moreover, in a study of 12 patients with SJS, $0.6 \mathrm{~g} / \mathrm{kg} /$ day of IVIG administered over 4 days resulted in a shorter recovery time and a mortality rate of 0 compared to other patients treated with corticosteroids and supportive care [5]. A study in India suggested that low-dose IVIG combined with steroids reduced mortality and recovery time compared to treatment with only steroids [119]. Husain et al. suggested that DRESS patients with life-threatening signs (renal and/or respiratory failure, encephalitis, severe hepatitis) can be treated with steroids combined with IVIG at a dose of $2 \mathrm{~g} / \mathrm{kg}$ over 5 days. IVIG should not be administered without associated steroids [86, 120]. In a systematic review and meta-analysis, high-dose IVIG treatment was not found to be beneficial to patients, but early use of IVIG can decrease mortality [121, 122]. More than one study found that IVIG at either low or high doses did not show benefit in terms of expected mortality at either low or high doses ( $<3 \mathrm{~g} / \mathrm{kg}$ vs $\geq 3 \mathrm{~g} / \mathrm{kg}$, respectively) $[123,124]$. IVIG may have adverse reactions, such as pulmonary embolism and hemorrhagic syndrome, and the exact timing and dosage require further examination.

\section{Cyclosporine}

Alternatively, recent studies have shown cyclosporine to be a promising treatment for drug eruption. Cyclosporine can inhibit nuclear transcription factor-kappa B (NF-kB), FasL, and TNF- $\alpha$, including the inhibition of $\mathrm{CD} 8+$ cytotoxicity mechanism; thus, it has powerful immunosuppressive and anti-apoptotic effects [125, 126]. When patients were given cyclosporine orally at a dose of $3 \mathrm{mg} / \mathrm{kg} /$ day for 10 days, which was then tapered for over a month, both the death rate and the progression of detachment were lower than those of
SCORTEN [127]. In a cohort study, it was found that the survival rate of patients treated with cyclosporine was higher than that of patients treated with IVIG [128]. Six DIHS/ DRESS cases were treated with a low dose (150-350 mg/day) of cyclosporine for 7 days or less, and all were cured without recurrence [129-131]. According to reports, the therapeutic effect of cyclosporine may take over a month. However, severe drug eruption progresses rapidly and requires timely and early treatment. In addition, it is worth noting that cyclosporine may aggravate liver and kidney damage in patients with severe drug eruption. Therefore, it is recommended to avoid using cyclosporine $\mathrm{A}$ alone in the acute phase [101].

\section{Plasmapheresis}

More than one decade of research has reported plasmapheresis to be effective in patients with TEN and DRESS [104, 132-136]. The exact mechanism of plasmapheresis is not clear; it has been found that after plasma replacement therapy, the patient's IL-2, IL-6, TNF- $\alpha$, interferon-gamma, FasL, and toxin levels were significantly reduced [137]. El-Azhary et al. suggested that plasmapheresis can effectively remove pathogenic factors and improve prognosis [138]. However, studies have pointed out that the use of plasma exchange to treat TEN does not improve the mortality, duration of the disease, or skin healing time $[124,139]$. Giudice $G$ reported that the administration of cyclosporine A at a dose of $250 \mathrm{mg}$ /day for adults (children dose at $4 \mathrm{mg} / \mathrm{kg} /$ day) for a total of 15 days, combined with seven cycles of plasmapheresis, greatly reduced TEN mortality, as compared to other supportive and topical therapies [140]. Whether blood purification is more beneficial if used alone or in combination with IVIG and/or glucocorticoids for patients with severe drug rashes requires confirmation from more randomized-controlled studies.

\section{Other Therapies}

Thalidomide can inhibit TNF- $\alpha$ [141]. However, a doubleblind, randomized, placebo-controlled study using thalidomide to treat TEN was aborted because of the high mortality rate [142]. Laban et al. reported a case of DRESS with associated interstitial nephritis and eye involvement that was treated with glucocorticoid, plasmapheresis, and cyclophosphamide [143]. However, six patients with TEN treated with cyclophosphamide (150 mg every $12 \mathrm{~h}$ ) and $\geq 1 \mathrm{mg} / \mathrm{kg}$ of 6-methylprednisolone every day had worse effects compared to 11 patients with TEN treated with $3 \mathrm{mg} / \mathrm{kg}$ of cyclosporine twice a day [144]. It is currently believed that Epstein-Barr virus (EBV) may be the key factor in the development of the secondary autoimmune disease of DRESS, and some studies have indicated that cytomegalovirus reactivation may be the cause of a variety of complications. Therefore, cytomegalovirus (CMV) and EBV should be detected and treated with anti-CMV/EBV as soon as possible [23, 45]. 
Valganciclovir targeting at HHV-6 and HHV-7 is recommended for DRESS with viral reactivation. However, the mechanism and dosage require further study [117].

Etanercept can inhibit lymphotoxin $\alpha$ and TNF- $\alpha$. A previous study of 10 patients with DRESS demonstrated a median healing time of 8.5 days after a 50-mg subcutaneous injection of etanercept [145]. Ling et al. successfully cured one case of SJS by subcutaneous injection of etanercept (initial dose $50 \mathrm{mg}$, then $25 \mathrm{mg}$ per day for 3 days). Hunger et al. treated a 69 -year-old TEN patient with anti-TNF- $\alpha$ antibodies (infliximab, $5 \mathrm{mg} / \mathrm{kg}$ ) and confirmed that their recovery time was significantly shorter than that of patients treated with immunoglobulin $[145,146]$. Wang et al. found similar mortality rates in patients treated with etanercept and corticosteroids, but those receiving etanercept had faster recovery [147]. Mepolizumab has been used to successfully treat eosinophilic diseases, such as hypereosinophilic syndrome and severe asthma [148]. As DRESS patients are often accompanied by hyperplasia with eosinophilia or the emergence of abnormal lymphocytes, Ange et al. reported successful treatment of DRESS patients with mepolizumab [149]. However, whether mepolizumab contributes to the treatment of severe drug eruption needs further study. Uzun et al. first reported that TEN can be treated with omalizumab (anti-IgE antibody). They monitored changes in immunoglobulin (Ig), C-reactive protein, serum eosinophile cationic protein, IgA, IgM, IgG1, IgG2, IgG3, IgG4, IgA, and IgM; all of which showed a significant decrease after treatment. However, there is no other evidence on omalizumab treatment in drug eruption [150]. Granulocyte colony-stimulating factor may play a certain role in the treatment of DRESS by inhibiting hypersensitivity reactions and stimulating epithelial regeneration, but there is currently no strong evidence [151].

In summary, a standard treatment plan for severe drug eruption has not been established yet, but the basic treatment process is generally the same (Fig. 5). To decrease mortality and improve prognosis, more precise research is urgently needed.
Fig. 5 Basic management of SCARs

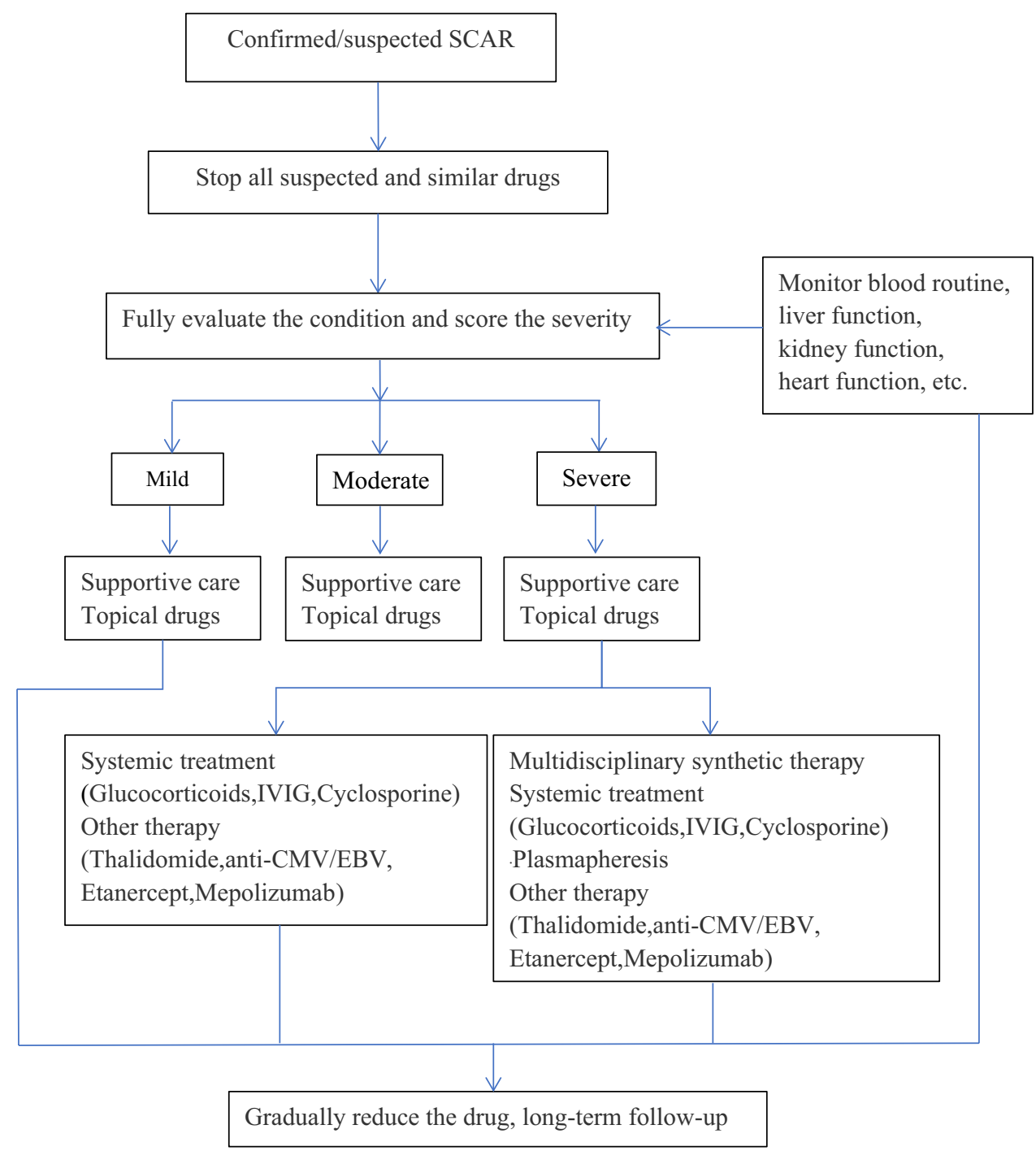




\section{Conclusion}

The pathogenesis of severe drug eruption is still being explored. Early diagnosis and management of severe drug eruption are very important for the prognosis of patients, and attention should be paid to possible long-term sequelae. There are various treatment options available, but traditional glucocorticoids and immunoglobulin therapies are still the first-choice treatments for severe drug eruption. Biological agents are emerging in the treatment of severe drug eruption, which may be the trend of the treatment of severe drug eruption in the future. The prevention of severe drug eruptions is also essential. The increasing number of studies on severe drug eruptions will be greatly beneficial and will guide the management of these patients.

\section{Declarations}

Conflict of Interest The authors declare no competing of interests.

\section{References}

1. International drug monitoring: the role of national centres. Report of a WHO meeting (1972). World Health Organization technical report series 498:1-25

2. Pirmohamed M, James S, Meakin S, Green C, Scott AK, Walley TJ, Farrar K, Park BK, Breckenridge AM (2004) Adverse drug reactions as cause of admission to hospital: prospective analysis of 18820 patients. BMJ (Clinical research ed) 329(7456):15-19. https://doi.org/10.1136/bmj.329.7456.15

3. Wester K, Jönsson AK, Spigset O, Druid H, Hägg S (2008) Incidence of fatal adverse drug reactions: a population based study. Br J Clin Pharmacol 65(4):573-579. https://doi.org/10.1111/j. 1365-2125.2007.03064.x

4. Riedl MA, Casillas AM (2003) Adverse drug reactions: types and treatment options. Am Fam Physician 68(9):1781-1790

5. Hoetzenecker W, Nägeli M, Mehra ET, Jensen AN, Saulite I, Schmid-Grendelmeier P, Guenova E, Cozzio A, French LE (2016) Adverse cutaneous drug eruptions: current understanding. Semin Immunopathol 38(1):75-86. https://doi.org/10.1007/ s00281-015-0540-2

6. Duong TA, Valeyrie-Allanore L, Wolkenstein P, Chosidow O (2017) Severe cutaneous adverse reactions to drugs. Lancet (London, England) 390(10106):1996-2011. https://doi.org/10.1016/ s0140-6736(16)30378-6

7. Yip VL, Alfirevic A, Pirmohamed M (2015) Genetics of immune-mediated adverse drug reactions: a comprehensive and clinical review. Clin Rev Allergy Immunol 48(2-3):165-175. https://doi.org/10.1007/s12016-014-8418-y

8. Ardern-Jones MR, Mockenhaupt M (2019) Making a diagnosis in severe cutaneous drug hypersensitivity reactions. Curr Opin Allergy Clin Immunol 19(4):283-293. https://doi.org/10.1097/ aci.0000000000000546

9. Valeyrie-Allanore L, Sassolas B, Roujeau JC (2007) Druginduced skin, nail and hair disorders. Drug Saf 30(11):10111030. https://doi.org/10.2165/00002018-200730110-00003
10. Levi N, Bastuji-Garin S, Mockenhaupt M, Roujeau JC, Flahault A, Kelly JP, Martin E, Kaufman DW, Maison P (2009) Medications as risk factors of Stevens-Johnson syndrome and toxic epidermal necrolysis in children: a pooled analysis. Pediatrics 123(2):e297-304. https://doi.org/10.1542/peds.2008-1923

11. Mockenhaupt M, Viboud C, Dunant A, Naldi L, Halevy S, Bouwes Bavinck JN, Sidoroff A, Schneck J, Roujeau JC, Flahault A (2008) Stevens-Johnson syndrome and toxic epidermal necrolysis: assessment of medication risks with emphasis on recently marketed drugs. The EuroSCAR-study. J Investig Dermatol 128 (1):35-44.https:// doi.org/10.1038/sj.jid.5701033

12. Sassolas B, Haddad C, Mockenhaupt M, Dunant A, Liss Y, Bork K, Haustein UF, Vieluf D, Roujeau JC, Le Louet H (2010) ALDEN, an algorithm for assessment of drug causality in Stevens-Johnson syndrome and toxic epidermal necrolysis: comparison with case-control analysis. Clin Pharmacol Ther 88(1):60-68. https://doi.org/10.1038/clpt.2009.252

13. Sekula P, Dunant A, Mockenhaupt M, Naldi L, Bouwes Bavinck JN, Halevy S, Kardaun S, Sidoroff A, Liss Y, Schumacher M, Roujeau JC (2013) Comprehensive survival analysis of a cohort of patients with Stevens-Johnson syndrome and toxic epidermal necrolysis. J Invest Dermatol 133(5):1197-1204. https://doi.org/ 10.1038/jid.2012.510

14. Amante MF, Filippini AV, Cejas N, Lendoire J, Imventarza O, Parisi C (2009) Dress syndrome and fulminant hepatic failure induced by lamotrigine. Ann Hepatol 8(1):75-77

15. Schöpf E, Stühmer A, Rzany B, Victor N, Zentgraf R, Kapp JF (1991) Toxic epidermal necrolysis and Stevens-Johnson syndrome. An epidemiologic study from West Germany. Arch Dermatol 127(6):839-842. https://doi.org/10.1001/archderm.1991. 01680050083008

16. Revuz J, Penso D, Roujeau JC, Guillaume JC, Payne CR, Wechsler J, Touraine R (1987) Toxic epidermal necrolysis. Clinical findings and prognosis factors in 87 patients. Arch Dermatol 123(9):1160-1165. https://doi.org/10.1001/archderm.123.9.1160

17. Pereira FA, Mudgil AV, Rosmarin DM (2007) Toxic epidermal necrolysis. J Am Acad Dermatol 56(2):181-200. https://doi.org/ 10.1016/j.jaad.2006.04.048

18. Borchers AT, Lee JL, Naguwa SM, Cheema GS, Gershwin ME (2008) Stevens-Johnson syndrome and toxic epidermal necrolysis. Autoimmun Rev 7(8):598-605. https://doi.org/10.1016/j. autrev.2008.06.004

19. Cacoub P, Musette P, Descamps V, Meyer O, Speirs C, Finzi L, Roujeau JC (2011) The DRESS syndrome: a literature review. Am J Med 124(7):588-597. https://doi.org/10.1016/j.amjmed. 2011.01.017

20. Chung SJ, Ahn KM, Oh JH, Shim JS, Park HW (2020) Incidence rates of severe cutaneous adverse reactions due to antiseizure medication: a nationwide study using health claims data in Korea. Epilepsia. https://doi.org/10.1111/epi.16751

21. Su SC, Hung SI, Fan WL, Dao RL, Chung WH (2016) Severe cutaneous adverse reactions: the pharmacogenomics from research to clinical implementation. Int J Cell Sci Mol 17(11). https://doi.org/10.3390/ijms17111890

22. Nguyen DV, Chu HC, Nguyen DV, Phan MH, Craig T, Baumgart K, van Nunen S (2015) HLA-B*1502 and carbamazepine-induced severe cutaneous adverse drug reactions in Vietnamese. Asia Pac Allergy 5(2):68-77. https://doi.org/10.5415/apallergy.2015.5.2. 68

23. Shiohara T, Mizukawa Y (2019) Drug-induced hypersensitivity syndrome (DiHS)/drug reaction with eosinophilia and systemic symptoms (DRESS): an update in 2019. Allergology international : official journal of the Japanese Society of Allergology 68(3):301-308. https://doi.org/10.1016/j.alit.2019.03.006

24. Hoosen K, Mosam A, Dlova NC, Grayson W (2019) An update on adverse cutaneous drug reactions in HIV/AIDS. 
Dermatopathology (Basel, Switzerland) 6(2):111-125. https:// doi.org/10.1159/000496389

25. Martinez-Lopez A, Cuenca-Barrales C, Montero-Vilchez T, Molina-Leyva A, Arias-Santiago S (2020) Review of adverse cutaneous reactions of pharmacologic interventions for COVID-19: a guide for the dermatologist. J Am Acad Dermatol 83(6):1738-1748. https://doi.org/10.1016/j.jaad.2020.08.006

26. Okamoto-Uchida Y, Nakamura R, Sai K, Imatoh T, Matsunaga K, Aihara M, Saito Y (2017) Effect of infectious diseases on the pathogenesis of Stevens-Johnson syndrome and toxic epidermal necrolysis. Biol Pharm Bull 40(9):1576-1580. https://doi.org/10. 1248/bpb.b17-00207

27. Chen CB, Wu MY, Ng CY, Lu CW, Wu J, Kao PH, Yang CK, Peng MT, Huang CY, Chang WC, Hui RC, Yang CH, Yang SF, Chung WH, Su SC (2018) Severe cutaneous adverse reactions induced by targeted anticancer therapies and immunotherapies. Cancer Manag Res 10:1259-1273. https://doi.org/10.2147/cmar. s163391

28. Halevy S, Ghislain PD, Mockenhaupt M, Fagot JP, Bouwes Bavinck JN, Sidoroff A, Naldi L, Dunant A, Viboud C, Roujeau JC (2008) Allopurinol is the most common cause of StevensJohnson syndrome and toxic epidermal necrolysis in Europe and Israel. J Am Acad Dermatol 58(1):25-32. https://doi.org/ 10.1016/j.jaad.2007.08.036

29. Abou-Taleb DAE, El-Sayed AM, Ghabesha AA, Hassan SB (2020) Severe cutaneous adverse drug reactions: incidence, clinical patterns, causative drugs and modalities of treatment in Assiut University Hospital, Upper Egypt. Dermatol Ther e14176. https://doi.org/10.1111/dth.14176

30. Nguyen DV, Vidal C, Chu HC, van Nunen S (2019) Human leukocyte antigen-associated severe cutaneous adverse drug reactions: from bedside to bench and beyond. Asia Pac Allergy 9(3):e20. https://doi.org/10.5415/apallergy.2019.9.e20

31. Kuijper EC, French LE, Tensen CP, Vermeer MH, Bouwes Bavinck JN (2020) Clinical and pathogenic aspects of the severe cutaneous adverse reaction epidermal necrolysis (EN). J Eur Acad Dermatol Venereol : JEADV 34(9):1957-1971. https:// doi.org/10.1111/jdv.16339

32. Mustafa SS, Ostrov D, Yerly D (2018) Severe cutaneous adverse drug reactions: presentation, risk factors, and management. Curr Allergy Asthma Rep 18(4):26. https://doi.org/10.1007/ s11882-018-0778-6

33. Shi Y, Tang R, Luo F, Li H, Pan Z, Xu G, Yang Y, Zhao Z, Liang A, Wei JF, Piao Y, Chang C, Sun JL, Platts-Mills TAE (2021) The diagnosis and management of allergic reactions caused by Chinese Materia Medica. Clin Rev Allergy Immunol. https://doi. org/10.1007/s12016-020-08812-7

34. Pettit C, Massick S, Bechtel M (2018) Cannabidiol-induced acute generalized exanthematous pustulosis. Dermatitis: contact, atopic, occupational, drug 29(6):345-346. https://doi.org/ $10.1097 /$ der.0000000000000422

35. Reap LE, Rodd C, Larios J, Marshall M (2019) Hydrochlorothizideinduced acute generalised exanthematous pustulosis presenting with bilateral periorbital impetigo. BMJ Case Reports 12(2). https:// doi.org/10.1136/bcr-2017-223528

36. Le Guern A, Kerrad I, Oehler E (2016) Severe cutaneous drug reactions to misused griseofulvin: 2 cases. Ann Dermatol Venereol 143(3):219-222. https://doi.org/10.1016/j.annder.2015. 12.012

37. Olivier S, De Montjoye L, Tromme I, Baeck M (2018) Two cases of annular acute generalized exanthematous pustulosis induced by terbinafine. Eur J Dermatol: EJD 28(2):236-238. https://doi. org/10.1684/ejd.2017.3199

38. Sarradin V, Dalenc F, Sibaud V, Tournier E, Roché H (2018) Acute generalized exanthematous pustulosis induced by docetaxel and recurrent with letrozole: a case report. Clin Breast
Cancer 18(5):e743-e746. https://doi.org/10.1016/j.clbc.2018.06. 009

39. Negrini S, Becquemont L (2017) Pharmacogenetics of hypersensitivity drug reactions. Therapie 72(2):231-243. https://doi.org/ 10.1016/j.therap.2016.12.009

40. Chung WH, Wang CW, Dao RL (2016) Severe cutaneous adverse drug reactions. J Dermatol 43(7):758-766. https://doi.org/10. 1111/1346-8138.13430

41. Alfirevic A, Pirmohamed M (2017) Genomics of adverse drug reactions. Trends Pharmacol Sci 38(1):100-109. https://doi.org/ 10.1016/j.tips.2016.11.003

42. Deng Y, Li S, Zhang L, Jin H, Zou X (2018) Association between HLA alleles and lamotrigine-induced cutaneous adverse drug reactions in Asian populations: a meta-analysis. Seizure 60:163171. https://doi.org/10.1016/j.seizure.2018.06.024

43. Ng CY, Chen CB, Wu MY, Wu J, Yang CH, Hui RC, Chang YC, Lu CW (2018) Anticancer drugs induced severe adverse cutaneous drug reactions: an updated review on the risks associated with anticancer targeted therapy or immunotherapies. J Immunol Res 2018:5376476. https://doi.org/10.1155/2018/5376476

44. Gagliani N, Amezcua Vesely MC, Iseppon A, Brockmann L, Xu H, Palm NW, de Zoete MR, Licona-Limón P, Paiva RS, Ching T, Weaver C, Zi X, Pan X, Fan R, Garmire LX, Cotton MJ, Drier Y, Bernstein B, Geginat J, Stockinger B, Esplugues E, Huber S, Flavell RA (2015) Th17 cells transdifferentiate into regulatory T cells during resolution of inflammation. Nature 523(7559):221225. https://doi.org/10.1038/nature14452

45. Shiohara T, Kano Y (2017) Drug reaction with eosinophilia and systemic symptoms (DRESS): incidence, pathogenesis and management. Expert Opin Drug Saf 16(2):139-147. https://doi.org/ 10.1080/14740338.2017.1270940

46. Riario Sforza GG, Marinou A (2017) Hypersensitivity pneumonitis: a complex lung disease. Clinical and molecular allergy : CMA 15:6. https://doi.org/10.1186/s12948-017-0062-7

47. Hung SI, Chung WH, Liou LB, Chu CC, Lin M, Huang HP, Lin YL, Lan JL, Yang LC, Hong HS, Chen MJ, Lai PC, Wu MS, Chu CY, Wang KH, Chen CH, Fann CS, Wu JY, Chen YT (2005) HLA-B*5801 allele as a genetic marker for severe cutaneous adverse reactions caused by allopurinol. Proc Natl Acad Sci USA 102(11):4134-4139. https://doi.org/10.1073/ pnas.0409500102

48. Navarini AA, Valeyrie-Allanore L, Setta-Kaffetzi N, Barker JN, Capon F, Creamer D, Roujeau JC, Sekula P, Simpson MA, Trembath RC, Mockenhaupt M, Smith CH (2013) Rare variations in IL36RN in severe adverse drug reactions manifesting as acute generalized exanthematous pustulosis. J Invest Dermatol 133(7):1904-1907. https://doi.org/10.1038/jid.2013.44

49. Ko TM, Chung WH, Wei CY, Shih HY, Chen JK, Lin CH, Chen YT, Hung SI (2011) Shared and restricted T-cell receptor use is crucial for carbamazepine-induced Stevens-Johnson syndrome. J Allergy Clin Immunol 128(6):1266-1276.e1211. https://doi.org/ 10.1016/j.jaci.2011.08.013

50. Chung WH, Pan RY, Chu MT, Chin SW, Huang YL, Wang WC, Chang JY, Hung SI (2015) Oxypurinol-specific T cells possess preferential TCR clonotypes and express granulysin in allopurinol-induced severe cutaneous adverse reactions. J Invest Dermatol 135(9):2237-2248. https://doi.org/10.1038/jid.2015.165

51. Cheng CY, Su SC, Chen CH, Chen WL, Deng ST, Chung WH (2014) HLA associations and clinical implications in T-cell mediated drug hypersensitivity reactions: an updated review. J Immunol Res 2014:565320. https://doi.org/10.1155/2014/565320

52. Chung WH, Chang WC, Lee YS, Wu YY, Yang CH, Ho HC, Chen MJ, Lin JY, Hui RC, Ho JC, Wu WM, Chen TJ, Wu T, Wu YR, Hsih MS, Tu PH, Chang CN, Hsu CN, Wu TL, Choon SE, Hsu CK, Chen DY, Liu CS, Lin CY, Kaniwa N, Saito Y, Takahashi Y, Nakamura R, Azukizawa H, Shi Y, Wang TH, 
Chuang SS, Tsai SF, Chang CJ, Chang YS, Hung SI (2014) Genetic variants associated with phenytoin-related severe cutaneous adverse reactions. JAMA 312(5):525-534. https://doi.org/ 10.1001/jama.2014.7859

53. Nicoletti P, Bansal M, Lefebvre C, Guarnieri P, Shen Y, Pe'er I, Califano A, Floratos A, (2015) ABC transporters and the proteasome complex are implicated in susceptibility to Stevens-Johnson syndrome and toxic epidermal necrolysis across multiple drugs. PLoS One 10(6):e0131038. https://doi.org/10.1371/journal.pone. 0131038

54. Wang W, Hu FY, Wu XT, An DM, Yan B, Zhou D (2014) Genetic susceptibility to the cross-reactivity of aromatic antiepileptic drugs-induced cutaneous adverse reactions. Epilepsy Res 108(6):1041-1045. https://doi.org/10.1016/j.eplepsyres.2014.03. 017

55. Neuman MG, McKinney KK, Nanau RM, Kong V, Malkiewicz I, Mazulli T, Moussa G, Cohen LB (2013) Drug-induced severe adverse reaction enhanced by human herpes virus- 6 reactivation. Translational research : the journal of laboratory and clinical medicine 161(5):430-440. https://doi.org/10.1016/j.trsl.2012. 12.012

56. Bastuji-Garin S, Fouchard N, Bertocchi M, Roujeau JC, Revuz J, Wolkenstein P (2000) SCORTEN: a severity-of-illness score for toxic epidermal necrolysis. J Invest Dermatol 115(2):149153. https://doi.org/10.1046/j.1523-1747.2000.00061.x

57. Wang LL, Noe MH, Micheletti RG (2020) Long-term sequelae from Stevens-Johnson syndrome / toxic epidermal necrolysis in a large retrospective cohort. J Am Acad Dermatol. https://doi. org/10.1016/j.jaad.2020.04.020

58. Lian SB, Oh CC, Yeo YW, Lee HY (2020) Spectrum of nail sequelae in Stevens-Johnson syndrome and toxic epidermal necrolysis. JAMA Dermatol. https://doi.org/10.1001/jamadermatol.2020.4664

59. Lefaucheur JP, Valeyrie-Allanore L, Ng Wing Tin S, Abgrall G, Colin A, Hajj C, de Prost N, Wolkenstein P, Ingen-Housz-Oro S, Chosidow O (2020) Chronic pain: a long-term sequela of epidermal necrolysis (Stevens-Johnson syndrome/toxic epidermal necrolysis) - prevalence, clinical characteristics and risk factors. J Eur Acad Dermatol Venereol: JEADV. https://doi.org/10.1111/ jdv. 16891

60. Yang J, Wang G, Fu M (2019) Drug reaction with eosinophilia and systemic symptoms presenting as leukoencephalopathy. J Dermatol 46(8):e305-e307. https://doi.org/10.1111/1346-8138. 14821

61. Vela JI, Bulnes V, Torrell N, Giró M, Perich S (2020) Bilateral marginal corneal infiltrates: a novel ocular manifestation of DRESS syndrome. Ocul Immunol Inflamm:1-3. https://doi.org/ 10.1080/09273948.2020.1797111

62. Kano Y, Ishida T, Hirahara K, Shiohara T (2010) Visceral involvements and long-term sequelae in drug-induced hypersensitivity syndrome. Med Clin North Am 94(4):743-759, xi. https://doi.org/10.1016/j.mcna.2010.03.004

63. Kardaun SH, Sekula P, Valeyrie-Allanore L, Liss Y, Chu CY, Creamer D, Sidoroff A, Naldi L, Mockenhaupt M, Roujeau JC (2013) Drug reaction with eosinophilia and systemic symptoms (DRESS): an original multisystem adverse drug reaction. Results from the prospective RegiSCAR study. Br J Dermatol 169(5):1071-1080. https://doi.org/10.1111/bjd.12501

64. Hollingsworth P, Paci K, Evans M, Miedema J, Morrell DS (2020) Alopecia universalis after drug reaction with eosinophilia and systemic symptoms (Dress). Pediatr Dermatol 37(5):947949. https://doi.org/10.1111/pde.14217

65. Bocquet H, Bagot M, Roujeau JC (1996) Drug-induced pseudolymphoma and drug hypersensitivity syndrome (Drug Rash with Eosinophilia and Systemic Symptoms: DRESS). Semin Cutan Med Surg 15(4):250-257. https://doi.org/10.1016/s10855629(96)80038-1
66. Criado PR, Criado RF, Avancini JM, Santi CG (2012) Drug reaction with eosinophilia and systemic symptoms (DRESS) / druginduced hypersensitivity syndrome (DIHS): a review of current concepts. An Bras Dermatol 87(3):435-449. https://doi.org/10. 1590/s0365-05962012000300013

67. Sidoroff A, Halevy S, Bavinck JN, Vaillant L, Roujeau JC (2001) Acute generalized exanthematous pustulosis (AGEP)-a clinical reaction pattern. J Cutan Pathol 28(3):113-119. https://doi.org/ 10.1034/j.1600-0560.2001.028003113.x

68. Hotz C, Valeyrie-Allanore L, Haddad C, Bouvresse S, Ortonne N, Duong TA, Ingen-Housz-Oro S, Roujeau JC, Wolkenstein P, Chosidow O (2013) Systemic involvement of acute generalized exanthematous pustulosis: a retrospective study on 58 patients. Br J Dermatol 169(6):1223-1232. https://doi.org/10.1111/bjd. 12502

69. Treudler R, Grunewald S, Gebhardt C, Simon JC (2009) Prolonged course of acute generalized exanthematous pustulosis with liver involvement due to sensitization to amoxicillin and paracetamol. Acta Derm Venereol 89(3):314-315. https://doi. org/10.2340/00015555-0616

70. Mohyuddin GR, Al Asad M, Scratchko L, Khaleeq G (2013) Acute generalized exanthematous pustulosis with multiple organ dysfunction syndrome. American journal of critical care : an official publication, American Association of Critical-Care Nurses 22(3):270-273. https://doi.org/10.4037/ajcc2013987

71. Eeckhout I, Noens L, Ongenae K, al Sarraf Z, Schelfhout A, Naeyaert JM, (1997) Acute generalized exanthematic pustulosis: a case with a lymphoma-like presentation. Dermatology (Basel, Switzerland) 194(4):408-410. https://doi.org/10.1159/ 000246163

72. Roujeau JC (2005) Clinical heterogeneity of drug hypersensitivity. Toxicology 209(2):123-129. https://doi.org/10.1016/j.tox. 2004.12.022

73. Hadavand MA, Kaffenberger B, Cartron AM, Trinidad JC (2020) Clinical presentation and management of atypical and recalcitrant acute generalized exanthematous pustulosis (AGEP). J Am Acad Dermatol. https://doi.org/10.1016/j.jaad.2020.09.024

74. Selvan S, Shakir R, Chan A (2013) Pustular vasculitis BMJ Case Reports. https://doi.org/10.1136/bcr-2013-008806

75. Hsu DY, Brieva J, Silverberg NB, Paller AS, Silverberg JI (2017) Pediatric Stevens-Johnson syndrome and toxic epidermal necrolysis in the United States. J Am Acad Dermatol 76(5):811-817. e814. https://doi.org/10.1016/j.jaad.2016.12.024

76. Metterle L, Hatch L, Seminario-Vidal L (2020) Pediatric drug reaction with eosinophilia and systemic symptoms: a systematic review of the literature. Pediatr Dermatol 37(1):124-129. https:// doi.org/10.1111/pde. 14044

77. Dibek Misirlioglu E, Guvenir H, Bahceci S, Haktanir Abul M, Can D, Usta Guc BE, Erkocoğlu M, Toyran M, Nacaroglu HT, Civelek E, Buyuktiryaki B, Ginis T, Orhan F, Kocabas CN (2017) Severe cutaneous adverse drug reactions in pediatric patients: a multicenter study. J Allergy Clin Immunol Pract 5(3):757-763. https://doi.org/10.1016/j.jaip.2017.02.013

78. López-Rocha E, Blancas L, Rodríguez-Mireles K, Gaspar-López A, O'Farrill-Romanillos P, Amaya-Mejía A, Galindo-Pacheco L, Campos-Romero F, Aguilar-Hinojosa N, Suárez G (2014) Prevalence of DRESS syndrome. Revista alergia Mexico (Tecamachalco, Puebla, Mexico : 1993) 61 (1):14-23

79. Botelho LF, Higashi VS, Padilha MH, Enokihara MM, Porro AM (2012) DRESS: clinicopathological features of 10 cases from an University Hospital in São Paulo. An Bras Dermatol 87(5):703707. https://doi.org/10.1590/s0365-05962012000500005

80. Kinoshita Y, Saeki H (2017) A review of toxic epidermal necrolysis management in Japan. Allergology international : official journal of the Japanese Society of Allergology 66(1):36-41. https://doi.org/10.1016/j.alit.2016.06.001 
81. Gupta LK, Martin AM, Agarwal N, D'Souza P, Das S, Kumar R, Pande S, Das NK, Kumaresan M, Kumar P, Garg A, Singh S (2016) Guidelines for the management of Stevens-Johnson syndrome/toxic epidermal necrolysis: an Indian perspective. Indian J Dermatol Venereol Leprol 82(6):603-625. https://doi.org/10. 4103/0378-6323.191134

82. Creamer D, Walsh SA, Dziewulski P, Exton LS, Lee HY, Dart JK, Setterfield J, Bunker CB, Ardern-Jones MR, Watson KM, Wong GA, Philippidou M, Vercueil A, Martin RV, Williams G, Shah M, Brown D, Williams P, Mohd Mustapa MF, Smith CH (2016) U.K. guidelines for the management of Stevens-Johnson syndrome/toxic epidermal necrolysis in adults 2016. Br J Dermatol 174 (6):1194-1227. https://doi.org/10.1111/bjd.14530

83. Macy E, Ngor E (2014) Recommendations for the management of beta-lactam intolerance. Clin Rev Allergy Immunol 47(1):4655. https://doi.org/10.1007/s12016-013-8369-8

84. Lerch M, Mainetti C, Terziroli Beretta-Piccoli B, Harr T (2018) Current perspectives on Stevens-Johnson syndrome and toxic epidermal necrolysis. Clin Rev Allergy Immunol 54(1):147-176. https://doi.org/10.1007/s12016-017-8654-z

85. Chanal J, Ingen-Housz-Oro S, Ortonne N, Duong TA, Thomas M, Valeyrie-Allanore L, Lebrun-Vignes B, André C, Roujeau JC, Chosidow O, Wolkenstein P (2013) Linear IgA bullous dermatosis: comparison between the drug-induced and spontaneous forms. Br J Dermatol 169(5):1041-1048. https://doi.org/10.1111/ bjd. 12488

86. Husain Z, Reddy BY, Schwartz RA (2013) DRESS syndrome: Part II. Management and therapeutics. J Am Acad Dermatol 68 (5):709.e701-709; quiz 718-720. https://doi.org/10.1016/j.jaad. 2013.01.032

87. Melish ME, Glasgow LA, Turner MD (1972) The staphylococcal scalded-skin syndrome: isolation and partial characterization of the exfoliative toxin. J Infect Dis 125(2):129-140. https://doi.org/ 10.1093/infdis/125.2.129

88. Rothenberger J, Krauss S, Held M, Bender D, Schaller HE, Rahmanian-Schwarz A, Constantinescu MA, Jaminet P (2014) A quantitative analysis of microcirculation in sore-prone pressure areas on conventional and pressure relief hospital mattresses using laser Doppler flowmetry and tissue spectrophotometry. J Tissue Viability 23(4):129-136. https://doi.org/10.1016/j.jtv. 2014.05.001

89. Palmieri TL, Greenhalgh DG, Saffle JR, Spence RJ, Peck MD, Jeng JC, Mozingo DW, Yowler CJ, Sheridan RL, Ahrenholz DH, Caruso DM, Foster KN, Kagan RJ, Voigt DW, Purdue GF, Hunt JL, Wolf S, Molitor F (2002) A multicenter review of toxic epidermal necrolysis treated in U.S. burn centers at the end of the twentieth century. J Burn Care Rehabil 23(2):87-96. https://doi. org/10.1097/00004630-200203000-00004

90. Stur K, Karlhofer FM, Stingl G (2007) Soluble FAS ligand: a discriminating feature between drug-induced skin eruptions and viral exanthemas. J Invest Dermatol 127(4):802-807. https://doi. org/10.1038/sj.jid.5700648

91. Lonjou C, Borot N, Sekula P, Ledger N, Thomas L, Halevy S, Naldi L, Bouwes-Bavinck JN, Sidoroff A, de Toma C, Schumacher M, Roujeau JC, Hovnanian A, Mockenhaupt M (2008) A European study of HLA-B in Stevens-Johnson syndrome and toxic epidermal necrolysis related to five high-risk drugs. Pharmacogenet Genomics 18(2):99-107. https://doi. org/10.1097/FPC.0b013e3282f3ef9c

92. Le Cleach L, Delaire S, Boumsell L, Bagot M, Bourgault-Villada I, Bensussan A, Roujeau JC (2000) Blister fluid T lymphocytes during toxic epidermal necrolysis are functional cytotoxic cells which express human natural killer (NK) inhibitory receptors. Clin Exp Immunol 119(1):225-230. https://doi.org/10.1046/j. 1365-2249.2000.01119.x
93. Tocco-Tussardi I, Huss F, Presman B (2017) Microbiological findings and antibacterial therapy in Stevens-Johnson syndrome/ toxic epidermal necrolysis patients from a Swedish Burn Center. J Cutan Pathol 44(5):420-432. https://doi.org/10.1111/cup.12894

94. Mathelier-Fusade P, Leynadier F (1995) The management of adverse drug reactions. Clin Rev Allergy Immunol 13(3):281290. https://doi.org/10.1007/bf02771767

95. Birchall N, Langdon R, Cuono C, McGuire J (1987) Toxic epidermal necrolysis: an approach to management using cryopreserved allograft skin. J Am Acad Dermatol 16(2 Pt 1):368-372. https://doi.org/10.1016/s0190-9622(87)70051-6

96. Heimbach DM, Engrav LH, Marvin JA, Harnar TJ, Grube BJ (1987) Toxic epidermal necrolysis. A step forward in treatment Jama 257(16):2171-2175

97. Macfarlane AW, Curley RK (1987) Management of toxic epidermal necrolysis with a hydrogel dressing and fluidized-bead bed: report of three cases. Clin Exp Dermatol 12(5):354-356. https:// doi.org/10.1111/j.1365-2230.1987.tb02508.x

98. Prasad JK, Feller I, Thomson PD (1986) Use of amnion for the treatment of Stevens-Johnson syndrome. J Trauma 26(10):945946. https://doi.org/10.1097/00005373-198610000-00016

99. Power WJ, Ghoraishi M, Merayo-Lloves J, Neves RA, Foster CS (1995) Analysis of the acute ophthalmic manifestations of the erythema multiforme/Stevens-Johnson syndrome/toxic epidermal necrolysis disease spectrum. Ophthalmology 102(11):16691676. https://doi.org/10.1016/s0161-6420(95)30811-1

100. Anquetil C, Salem JE, Lebrun-Vignes B, Touhami S, Desbois AC, Maalouf G, Domont F, Allenbach Y, Cacoub P, Bodaghi B, Saadoun D (2020) Evolving spectrum of drug-induced uveitis at the era of immune checkpoint inhibitors results from the WHO's pharmacovigilance database. J Autoimmun 111:102454. https:// doi.org/10.1016/j.jaut.2020.102454

101. Letko E, Papaliodis DN, Papaliodis GN, Daoud YJ, Ahmed AR, Foster CS (2005) Stevens-Johnson syndrome and toxic epidermal necrolysis: a review of the literature. Annals of allergy, asthma \& immunology : official publication of the American College of Allergy, Asthma, \& Immunology 94 (4):419-436; quiz 436-418, 456. https://doi.org/10.1016/s1081-1206(10)61112-x

102. Seczynska B, Nowak I, Sega A, Kozka M, Wodkowski M, Królikowski W, Szczeklik W (2013) Supportive therapy for a patient with toxic epidermal necrolysis undergoing plasmapheresis. Crit Care Nurse 33(4):26-38. https://doi.org/10.4037/ccn2013555

103. Dodiuk-Gad RP, Chung WH, Valeyrie-Allanore L, Shear NH (2015) Stevens-Johnson syndrome and toxic epidermal necrolysis: an update. Am J Clin Dermatol 16(6):475-493. https://doi. org/10.1007/s40257-015-0158-0

104. Dodiuk-Gad RP, Olteanu C, Feinstein A, Hashimoto R, Alhusayen R, Whyte-Croasdaile S, Finkelstein Y, Burnett M, Sade S, Cartotto R, Jeschke M, Shear NH (2016) Major psychological complications and decreased health-related quality of life among survivors of Stevens-Johnson syndrome and toxic epidermal necrolysis. Br J Dermatol 175(2):422-424. https://doi. org/10.1111/bjd.14799

105. Cervera R, Rodríguez-Pintó I, Espinosa G (2018) The diagnosis and clinical management of the catastrophic antiphospholipid syndrome: a comprehensive review. J Autoimmun 92:1-11. https://doi.org/10.1016/j.jaut.2018.05.007

106. Moncada B, Delgado C, Quevedo ME, Lorincz AL (1994) Abnormal T-cell response in toxic epidermal necrolysis. Arch Dermatol 130(1):116-117

107. Kocaoglu C, Cilasun C, Solak ES, Kurtipek GS, Arslan S (2013) Successful treatment of antiepileptic drug-induced DRESS syndrome with pulse methylprednisolone. Case reports in pediatrics 2013:928910. https://doi.org/10.1155/2013/928910

108. Bommersbach TJ, Lapid MI, Leung JG, Cunningham JL, Rummans TA, Kung S (2016) Management of psychotropic 
drug-induced DRESS syndrome: a systematic review. Mayo Clin Proc 91(6):787-801. https://doi.org/10.1016/j.mayocp. 2016.03.006

109. Shiohara T, Inaoka M, Kano Y (2006) Drug-induced hypersensitivity syndrome (DIHS): a reaction induced by a complex interplay among herpesviruses and antiviral and antidrug immune responses. Allergology international : official journal of the Japanese Society of Allergology 55(1):1-8. https://doi.org/10.2332/ allergolint.55.1

110. Gentile I, Talamo M, Borgia G (2010) Is the drug-induced hypersensitivity syndrome (DIHS) due to human herpesvirus 6 infection or to allergy-mediated viral reactivation? Report of a case and literature review. BMC Infect Dis 10:49. https://doi.org/10. 1186/1471-2334-10-49

111. Wei CH, Chung-Yee Hui R, Chang CJ, Ho HC, Yang CH, Lin YJ, Chung WH (2011) Identifying prognostic factors for drug rash with eosinophilia and systemic symptoms (DRESS). Eur J Dermatol: EJD 21(6):930-937. https://doi.org/10.1684/ejd.2011. 1550

112. Ang CC, Wang YS, Yoosuff EL, Tay YK (2010) Retrospective analysis of drug-induced hypersensitivity syndrome: a study of 27 patients. J Am Acad Dermatol 63(2):219-227. https://doi.org/ 10.1016/j.jaad.2009.08.050

113. Iannella G, Greco A, Didona D, Didona B, Granata G, Manno A, Pasquariello B, Magliulo G (2016) Vitiligo: pathogenesis, clinical variants and treatment approaches. Autoimmun Rev 15(4):335-343. https://doi.org/10.1016/j.autrev.2015.12.006

114. Guibal F, Bastuji-Garin S, Chosidow O, Saiag P, Revuz J, Roujeau JC (1995) Characteristics of toxic epidermal necrolysis in patients undergoing long-term glucocorticoid therapy. Arch Dermatol 131(6):669-672

115. Sherertz EF, Jegasothy BV, Lazarus GS (1985) Phenytoin hypersensitivity reaction presenting with toxic epidermal necrolysis and severe hepatitis. Report of a patient treated with corticosteroid "pulse therapy". J Am Acad Dermatol 12(1 Pt 2):178-181. https://doi.org/10.1016/s0190-9622(85)80012-8

116. Halebian PH, Corder VJ, Madden MR, Finklestein JL, Shires GT (1986) Improved burn center survival of patients with toxic epidermal necrolysis managed without corticosteroids. Ann Surg 204(5):503-512. https://doi.org/10.1097/00000658198611000-00001

117. Kuruvilla M, Khan DA (2016) Eosinophilic drug allergy. Clin Rev Allergy Immunol 50(2):228-239. https://doi.org/10.1007/ s12016-015-8491-x

118. Galvão VR, Aun MV, Kalil J, Castells M, Giavina-Bianchi P (2014) Clinical and laboratory improvement after intravenous immunoglobulin in drug reaction with eosinophilia and systemic symptoms. J Allergy Clin Immunol Pract 2(1):107-110. https://doi.org/10.1016/j.jaip.2013.11.008

119. Jagadeesan S, Sobhanakumari K, Sadanandan SM, Ravindran S, Divakaran MV, Skaria L, Kurien G (2013) Low dose intravenous immunoglobulins and steroids in toxic epidermal necrolysis: a prospective comparative open-labelled study of 36 cases. Indian J Dermatol Venereol Leprol 79(4):506-511. https://doi.org/10. 4103/0378-6323.113080

120. Zhu QY, Ma L, Luo XQ, Huang HY (2012) Toxic epidermal necrolysis: performance of SCORTEN and the score-based comparison of the efficacy of corticosteroid therapy and intravenous immunoglobulin combined therapy in China. Journal of burn care \& research : official publication of the American Burn Association 33(6):e295-308. https://doi.org/10.1097/ BCR.0b013e318254d2ec

121. Aires DJ, Fraga G, Korentager R, Richie CP, Aggarwal S, Wick J, Liu DY (2013) Early treatment with nonsucrose intravenous immunoglobulin in a burn unit reduces toxic epidermal necrolysis mortality. J Drugs Dermatol: JDD 12(6):679-684
122. Prins C, Kerdel FA, Padilla RS, Hunziker T, Chimenti S, Viard I, Mauri DN, Flynn K, Trent J, Margolis DJ, Saurat JH, French LE (2003) Treatment of toxic epidermal necrolysis with highdose intravenous immunoglobulins: multicenter retrospective analysis of 48 consecutive cases. Arch Dermatol 139(1):26-32. https://doi.org/10.1001/archderm.139.1.26

123. Lee HY, Lim YL, Thirumoorthy T, Pang SM (2013) The role of intravenous immunoglobulin in toxic epidermal necrolysis: a retrospective analysis of 64 patients managed in a specialized centre. Br J Dermatol 169(6):1304-1309. https://doi.org/10. 1111/bjd.12607

124. Zimmermann S, Sekula P, Venhoff M, Motschall E, Knaus J, Schumacher M, Mockenhaupt M (2017) Systemic immunomodulating therapies for Stevens-Johnson syndrome and toxic epidermal necrolysis: a systematic review and metaanalysis. JAMA Dermatol 153(6):514-522. https://doi.org/ 10.1001/jamadermatol.2016.5668

125. Viard I, Wehrli P, Bullani R, Schneider P, Holler N, Salomon D, Hunziker T, Saurat JH, Tschopp J, French LE (1998) Inhibition of toxic epidermal necrolysis by blockade of CD95 with human intravenous immunoglobulin. Science (New York, NY) 282(5388):490-493. https://doi.org/10.1126/science.282.5388.490

126. Paquet P, Nikkels A, Arrese JE, Vanderkelen A, Piérard GE (1994) Macrophages and tumor necrosis factor alpha in toxic epidermal necrolysis. Arch Dermatol 130(5):605-608

127. Valeyrie-Allanore L, Wolkenstein P, Brochard L, Ortonne N, Maître B, Revuz J, Bagot M, Roujeau JC (2010) Open trial of ciclosporin treatment for Stevens-Johnson syndrome and toxic epidermal necrolysis. Br J Dermatol 163(4):847-853. https:// doi.org/10.1111/j.1365-2133.2010.09863.x

128. Kirchhof MG, Miliszewski MA, Sikora S, Papp A, Dutz JP (2014) Retrospective review of Stevens-Johnson syndrome/ toxic epidermal necrolysis treatment comparing intravenous immunoglobulin with cyclosporine. J Am Acad Dermatol 71(5):941-947. https://doi.org/10.1016/j.jaad.2014.07.016

129. Zuliani E, Zwahlen H, Gilliet F, Marone C (2005) Vancomycininduced hypersensitivity reaction with acute renal failure: resolution following cyclosporine treatment. Clin Nephrol 64(2):155158. https://doi.org/10.5414/cnp64155

130. Zhang ZX, Yang BQ, Yang Q, Wu M, Wang GJ (2017) Treatment of drug-induced hypersensitivity syndrome with cyclosporine. Indian J Dermatol Venereol Leprol 83(6):713-717. https://doi. org/10.4103/ijdvl.IJDVL_1084_16

131. Kirchhof MG, Wong A, Dutz JP (2016) Cyclosporine treatment of drug-induced hypersensitivity syndrome. JAMA Dermatol 152(11):1254-1257. https://doi.org/10.1001/jamadermatol.2016. 2220

132. Schneider JA, Cohen PR (2017) Stevens-Johnson syndrome and toxic epidermal necrolysis: a concise review with a comprehensive summary of therapeutic interventions emphasizing supportive measures. Adv Ther 34(6):1235-1244. https://doi.org/ 10.1007/s12325-017-0530-y

133. Egan CA, Grant WJ, Morris SE, Saffle JR, Zone JJ (1999) Plasmapheresis as an adjunct treatment in toxic epidermal necrolysis. J Am Acad Dermatol 40(3):458-461. https://doi.org/10.1016/ s0190-9622(99)70497-4

134. Sakellariou G, Koukoudis P, Karpouzas J, Alexopoulos E, Papadopoulou D, Chrisomalis F, Skenteris N, Tsakaris D, Papadimitriou M (1991) Plasma exchange (PE) treatment in drug-induced toxic epidermal necrolysis (TEN). Int J Artif Organs 14(10):634-638

135. Kamanabroo D, Schmitz-Landgraf W, Czarnetzki BM (1985) Plasmapheresis in severe drug-induced toxic epidermal necrolysis. Arch Dermatol 121(12):1548-1549

136. Konstantinow A, Mühlbauer W, Balda BR, Ring J (2001) [Toxic epidermal necrolysis (drug-induced Lyell's syndrome). 
2. Treatment]. Deutsche medizinische Wochenschrift (1946) 126(7):177-179. https://doi.org/10.1055/s-2001-11190

137. Narita YM, Hirahara K, Mizukawa Y, Kano Y, Shiohara T (2011) Efficacy of plasmapheresis for the treatment of severe toxic epidermal necrolysis: is cytokine expression analysis useful in predicting its therapeutic efficacy? J Dermatol 38(3):236-245. https://doi.org/10.1111/j.1346-8138.2010.01154.x

138. El-Azhary RA, Wang MZ, Wentworth AB, Hickson LJ (2018) Treatment of severe drug reactions by hemodialysis. Int J Dermatol 57(2):177-182. https://doi.org/10.1111/ijd.13837

139. Furubacke A, Berlin G, Anderson C, Sjöberg F (1999) Lack of significant treatment effect of plasma exchange in the treatment of drug-induced toxic epidermal necrolysis? Intensive Care Med 25(11):1307-1310. https://doi.org/10.1007/s001340051063

140. Giudice G, Maggio G, Bufano L, Memeo G, Vestita M (2017) Management of toxic epidermal necrolysis with plasmapheresis and cyclosporine A: our 10 years' experience. Plast Reconstr Surg Glob Open 5(2):e1221. https://doi.org/10.1097/gox. 0000000000001221

141. Klausner JD, Freedman VH, Kaplan G (1996) Thalidomide as an anti-TNF-alpha inhibitor: implications for clinical use. Clin Immunol Immunopathol 81(3):219-223. https://doi.org/10.1006/ clin.1996.0181

142. Wolkenstein P, Latarjet J, Roujeau JC, Duguet C, Boudeau S, Vaillant L, Maignan M, Schuhmacher MH, Milpied B, Pilorget A, Bocquet H, Brun-Buisson C, Revuz J (1998) Randomised comparison of thalidomide versus placebo in toxic epidermal necrolysis. Lancet (London, England) 352(9140):1586-1589. https://doi.org/10.1016/s0140-6736(98)02197-7

143. Laban E, Hainaut-Wierzbicka E, Pourreau F, Yacoub M, Sztermer E, Guillet G, Touchard G, Bridoux F (2010) Cyclophosphamide therapy for corticoresistant drug reaction with eosinophilia and systemic symptoms (DRESS) syndrome in a patient with severe kidney and eye involvement and Epstein-Barr virus reactivation. Am J Kidney Dis 55(3):e11-14. https://doi.org/10.1053/j. ajkd.2009.10.054

144. Arévalo JM, Lorente JA, González-Herrada C, Jiménez-Reyes J (2000) Treatment of toxic epidermal necrolysis with cyclosporin A. J Trauma 48(3):473-478. https://doi.org/10.1097/00005373200003000-00017
145. Paradisi A, Abeni D, Bergamo F, Ricci F, Didona D, Didona B (2014) Etanercept therapy for toxic epidermal necrolysis. J Am Acad Dermatol 71(2):278-283. https://doi.org/10.1016/j.jaad. 2014.04.044

146. Hunger RE, Hunziker T, Buettiker U, Braathen LR, Yawalkar N (2005) Rapid resolution of toxic epidermal necrolysis with antiTNF-alpha treatment. J Allergy Clin Immunol 116(4):923-924. https://doi.org/10.1016/j.jaci.2005.06.029

147. Wang CW, Yang LY, Chen CB, Ho HC, Hung SI, Yang CH, Chang CJ, Su SC, Hui RC, Chin SW, Huang LF, Lin YY, Chang WY, Fan WL, Yang CY, Ho JC, Chang YC, Lu CW, Chung WH (2018) Randomized, controlled trial of TNF- $\alpha$ antagonist in CTL-mediated severe cutaneous adverse reactions. J Clin Investig 128(3):985-996. https://doi.org/10.1172/jci93349

148. Wechsler ME, Akuthota P, Jayne D, Khoury P, Klion A, Langford CA, Merkel PA, Moosig F, Specks U, Cid MC, Luqmani R, Brown J, Mallett S, Philipson R, Yancey SW, Steinfeld J, Weller PF, Gleich GJ (2017) Mepolizumab or placebo for eosinophilic granulomatosis with polyangiitis. N Engl J Med 376(20):19211932. https://doi.org/10.1056/NEJMoa1702079

149. Ange N, Alley S, Fernando SL, Coyle L, Yun J (2018) Drug reaction with eosinophilia and systemic symptoms (DRESS) syndrome successfully treated with mepolizumab. J Allergy Clin Immunol Pract 6(3):1059-1060. https://doi.org/10.1016/j.jaip. 2017.10.020

150. Uzun R, Yalcin AD, Celik B, Bulut T, Yalcin AN (2016) Levofloxacin induced toxic epidermal necrolysis: successful therapy with omalizumab (anti-IgE) and pulse prednisolone. The American journal of case reports 17:666-671. https://doi.org/10.12659/ ajcr.899823

151. de Sica-Chapman A, Williams G, Soni N, Bunker CB (2010) Granulocyte colony-stimulating factor in toxic epidermal necrolysis (TEN) and Chelsea \& Westminster TEN management protocol [corrected]. Br J Dermatol 162(4):860-865. https://doi.org/ $10.1111 / \mathrm{j} .1365-2133.2009 .09585 . \mathrm{x}$

Publisher's Note Springer Nature remains neutral with regard to jurisdictional claims in published maps and institutional affiliations. 